Original paper

\title{
Geochemistry and petrology of pyroxenite xenoliths from Cenozoic alkaline basalts, Bohemian Massif
}

\author{
Lukáš ACKERMAN ${ }^{1} 2^{2 *}$, Petr ŠPAČEK ${ }^{3}$, Gordon MEDARIS, Jr. ${ }^{4}$, Ernst HEGNER ${ }^{5}$, Martin SVOJTKA ${ }^{1}$, \\ Jaromír ULRYCH ${ }^{1}$ \\ ${ }^{1}$ Institute of Geology v.v.i., Academy of Sciences of the Czech Republic, Rozvojová 269, 16500 Prague 6, Czech Republic; \\ ackerman@gli.cas.cz \\ ${ }^{2}$ Czech Geological Survey, Geologická 6, 15000 Prague 5, Czech Republic \\ ${ }^{3}$ Institute of Geophysics v.vi., Academy of Sciences of the Czech Republic, Bočni II, 14134 Prague 4, Czech Republic \\ ${ }^{4}$ Department of Geoscience, University of Wisconsin-Madison, WI 53706, USA \\ ${ }^{5}$ Department für Geowissenschaften, Universität München, Theresienstraße 41, D-8033 München, Germany \\ * Corresponding author
}

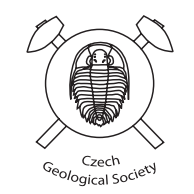

Pyroxenites occur as rare, but important, mantle xenoliths within Cenozoic volcanic rocks of the Central European Volcanic Province (CEVP). We report the petrography, geothermobarometry, mineral chemistry as well as clinopyroxene trace-element and $\mathrm{Sr}-\mathrm{Nd}$ isotopic compositions of six pyroxenite xenoliths hosted by Tertiary-Quaternary volcanic rocks from Kozákov (NE Bohemia), Dobkovičky and Kuzov (Ohře/Eger Rift), and Lutynia (SW Poland). Three Kozákov xenoliths record a complex nature and evolution. As suggested by contrasting estimated temperatures $\left(596-663^{\circ} \mathrm{C}\right.$ and $1008-1067^{\circ} \mathrm{C}$ ) and textures, olivine clinopyroxenite and one websterite were likely derived from different depths and may represent crystallization products of transient melts. Another websterite contains symplectite pseudomorphs after garnet which originated by exsolution from highly aluminous clinopyroxene, and the garnet breakdown was associated with melt introduction. This websterite P-T conditions (17.3 to $21.4 \mathrm{kbar}$ and $1080-1200{ }^{\circ} \mathrm{C}$ ) correspond to derivation from depths of 55-69 km. The composition of websterite from Dobkovičky suggests its origin as a cumulate from melt derived from a highly depleted mantle source with a composition similar to Depleted MORB Mantle (DMM). The position and petrological significance of websterite from Kuzov remains unclear because of a lack of data from associated peridotites. At Lutynia, cryptic metasomatism of peridotites by a $\mathrm{CO}_{2}$-bearing alkaline melt was described previously, and the composition of melt calculated to be in equilibrium with Lutynia websterite clinopyroxene is very similar to that in equilibrium with metasomatized amphibole-bearing peridotite. Therefore, the Lutynia websterite may represent a cumulate from percolating melt that metasomatized the lithospheric mantle in this area.

Keywords: pyroxenite, xenolith, Cenozoic, basalt, Sr-Nd isotopes, geothermobarometry

Received: 7 August 2012; accepted: 13 November 2012; handling editor: J. Kotková

\section{Introduction}

Pyroxenite is a volumetrically minor, but petrologically significant, mantle rock type found in mafic-ultramafic series. Pyroxenites usually form layers, veins, or dikes in orogenic peridotites and occur as xenoliths of variable sizes and shapes in volcanic rocks. Their compositions range from orthopyroxenite through websterite to clinopyroxenite, with variable modal contents of olivine and the common presence of garnet and/or spinel. The origin of pyroxenites is still largely debated (Downes 2007; Gonzaga et al. 2010a, b), and diverse processes of formation have been proposed, such as crystallization from silicate melts passing through the lithospheric mantle (e.g., Frey 1980; Loubet and Allègre 1982; Witt-Eickschen and Kramm 1998; Puziewicz et al. 2011), in-situ melting/ dissolution of pyroxenes and their subsequent precipitation in pyroxenite layers (Dick and Sinton 1979; Chen et al. 2001), melt-rock reaction between peridotite and transient basaltic melts (Porreca et al. 2006; Ackerman et al. 2009), and high-pressure crystal accumulation from subduction-related melts (Davies et al. 1993; Pearson et al. 1993; Medaris et al. 1995).

In this paper, we present the petrography, major- and trace-element compositions of minerals, and $\mathrm{Sr}$ and $\mathrm{Nd}$ isotopic data for clinopyroxene in six mantle pyroxenite xenoliths from the Bohemian Massif. The xenoliths are hosted by Tertiary-Quaternary alkaline basalts of the Central European Volcanic Province (CEVP; Wilson and Downes 1991). The data reveal a spectrum of xenolith compositions and characteristics that are interpreted in the context of various magmatic processes and mantle sources. 


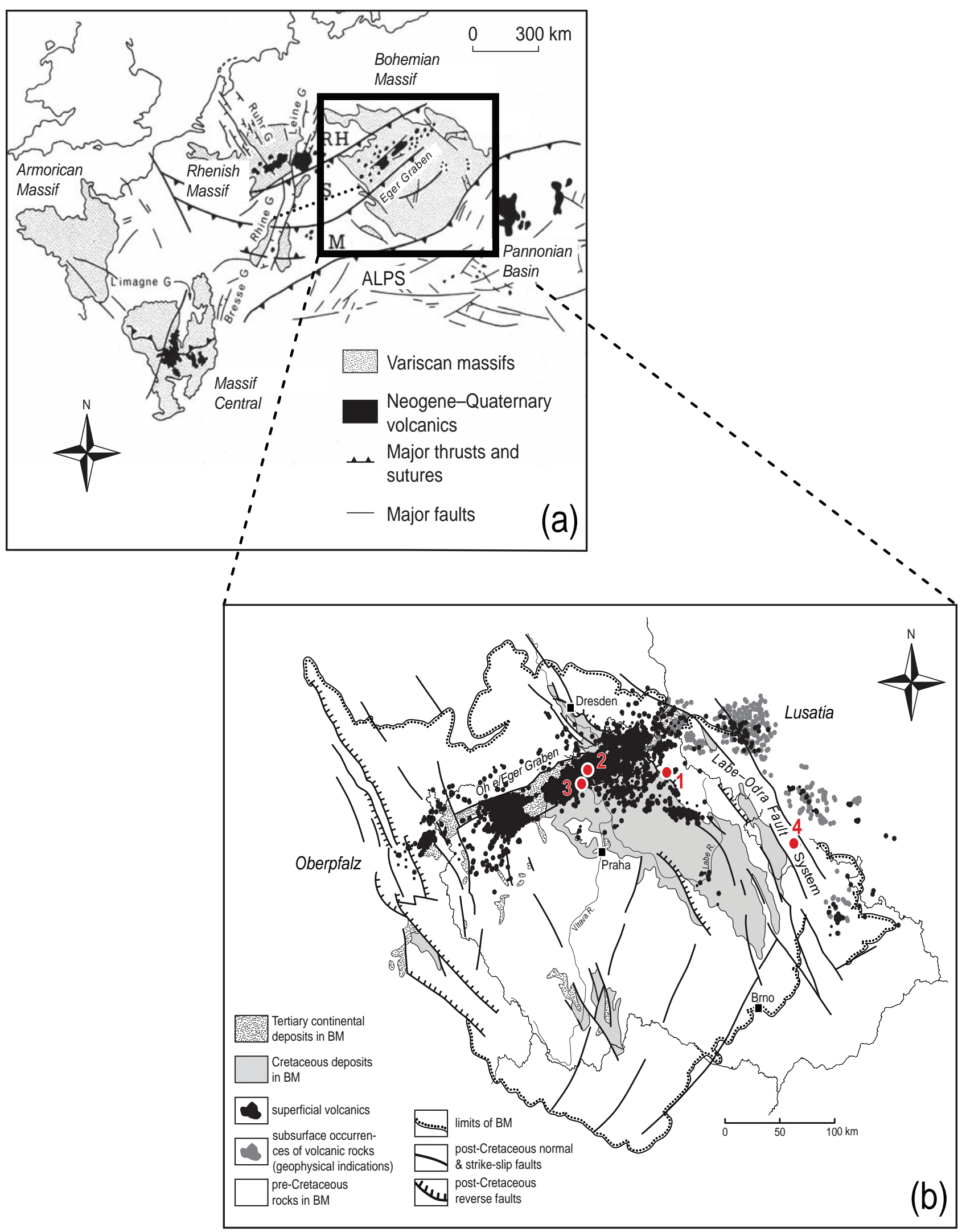

Fig. 1a The distribution of Variscan massifs, terranes and Tertiary to Quaternary volcanic rocks in Europe (RH, Rhenohercynian; S, Saxothuringian; M, Moldanubian; modified from Franke 1989; Wilson and Downes 1991). b - Geological sketch map of Cenozoic volcanic rocks in the Bohemian Massif (modified from Ulrych et al. 2011). Studied localities are highlighted by red dots. 1 - Kozákov, 2 - Dobkovičky, 3 - Kuzov, 4 - Lutynia. 


\section{Geological setting and sample localities}

Cenozoic volcanism forms several centers within the extensive European Cenozoic rift system including the Variscan basement of Spain, the French Massif Central, the Rhine Graben, the Rhenish Massif, the Lower Rhine Embayment and Hessen Depression (Prodehl et al. 1995) and the easternmost part of the rift system, the ENE-WSW trending Ohře/Eger Graben in the Bohemian Massif (Kopecký 1978; Ziegler 1994). Cenozoic alkaline volcanic rocks are also exposed farther north to Lusatia and south to the Oberpfalz (Fig. 1). Geophysical evidence indicates that the thickness of the lithosphere beneath the western Ohře Graben is $\sim 80$ km (Babuška and Plomerová 1992; Babuška et al. 2010; Babuška and Plomerová 2010). The other volcano-tectonic zones of the Bohemian Massif are the Cheb-Domažlice Graben in western Bohemia (Ulrych et al. 2003) and the Labe/Elbe-Odra Fault System with dispersed volcanic centers in northeastern Bohemia (Fediuk and Fediuková 1985; Birkenmajer et al. 2004; Ulrych et al. 2011). Based on ages, geochemical and mineralogical characteristics, and the paleostress chart for the Bohemian Massif, three main intervals of Late Cretaceous to Cenozoic volcanic activity have been identified at 79-49, 42-16 and 16-0.26 Ma (Ulrych et al. 2011). Mantle xenoliths, predominantly peridotite, are abundant in the volcanic rocks of all three episodes with a maximum abundance in the main syn-rift Eocene to Miocene period, which is characterized by strongly alkaline nephelinite-tephrite-phonolite series and weakly alkaline olivine nephelinite-basanite-trachyte series.

Mantle pyroxenite xenoliths in Cenozoic basalts are rare, and their origin and role during mantle metasomatism is sparsely documented so far. The composition of CEVP pyroxenite xenoliths varies from clinopyroxenite through websterite to rare orthopyroxenite; most pyroxenites contain spinel, and some, olivine (e.g., Fediuk 1994; Witt-Eickschen and Kramm 1998; Ulrych et al. 2000; Witt-Eickschen et al. 2003; Galán et al. 2011; Puziewicz et al. 2011).

We studied pyroxenite xenoliths from four different nepheline basanite suites in the Bohemian Massif (Fig. 1): (1) Kozákov volcano located in NE Bohemia on the Lusatian Fault System, which is part of the Labe/Elbe-Odra Fault System (Ulrych et al. 2011), (2) Dobkovičky lava flows associated with the Litochovice Fault System in the Ohře/Eger Rift, (3) Kuzov dikes located on the Třebívlice Fault in the Ohře/Eger Rift, and (4) Lutynia volcanic plug and lava flows in SW Poland associated with the Labe/ Elbe-Odra Fault System in the Western Sudetes.

\subsection{Kozákov volcano}

The 3.5-6.7 Ma (K-Ar age) old Kozákov volcano (Šibrava and Havlíček 1980; Lustrino and Wilson 2007) comprises nepheline basaltic flows and hosts abundant spinel lher- zolite xenoliths accompanied by subordinate harzburgite, dunite and rare pyroxenite xenoliths (Fediuk 1994). Based on geothermobarometry, whole-rock geochemistry, geothermal considerations and geophysical data, Christensen et al. (2001) and Ackerman et al. (2007) have shown that the upper mantle beneath the Kozákov volcano is layered, consisting of two layers of equigranular peridotite at depth intervals of $\sim 32-43 \mathrm{~km}$ and $\sim 65-70 \mathrm{~km}$ and an intervening layer of protogranular peridotite at $\sim 43-65 \mathrm{~km}$. This layered mantle section experienced variable degrees of partial melting from 5 to $17 \%$ depending on the depth (decreasing depletion with increasing depth). Subsequent metasomatism of a depleted lherzolite protolith, most likely by a silicate melt, produced enrichment in the large ion lithophile elements, light rare earth elements and high field strength elements (Ackerman et al. 2007).

\subsection{Dobkovičky quarry}

Massive flows of nepheline basanite, dated at $29.5 \mathrm{Ma}(\mathrm{K}-$ Ar age - Lustrino and Wilson 2007), are exposed in large quarries on both sides of the Labe/Elbe River and belong to a $100 \mathrm{~m}$-thick sequence of basaltic lavas in the central part of the České Středohoří Mts. in the Ohře/Eger Rift. In the Dobkovičky quarry, mantle xenoliths consist of abundant spinel harzburgite and rare lherzolite and pyroxenite. The xenoliths (mostly tabular in shape, up to $15 \mathrm{~cm}$ in diameter) are commonly pervasively hydrothermally altered and infiltrated by nephelinite. Frýda and Vokurka (1995) studied unusual harzburgite xenoliths containing secondary apatite and calcite. They interpreted the $\mathrm{Sr}-\mathrm{Nd}$ isotopic compositions of calcite as an evidence for origin of the secondary minerals by carbonatitic melt/fluid metasomatism at mantle depths, rather than overprinting by the host basanite magma. Rare clinopyroxenite xenoliths up to $7 \mathrm{~cm}$ in diameter were briefly described by Mihaljevič (1993) as almost monomineralic Cr-clinopyroxene rocks replaced by chlorite.

\subsection{Kuzov Hill}

Kuzov Hill is located in the České Středohoři Mts. (Ohře/Eger Rift) and is formed by two intersecting sets of nepheline basanite dykes that are exposed in abandoned local quarries. Both dykes contain mantle xenoliths of spinel lherzolite and dunite (usually up to $5 \mathrm{~cm}$ in diameter) which are accompanied by rare clinopyroxenite xenoliths.

\subsection{Lutynia village}

The Lutynia locality consists of a volcanic plug and associated lava flows that are exposed in active (Lutynia II) and abandoned (Lutynia I) quarries at the village of 
Szwedzkie Szance NNE of the town of Lądek Zdrój, SW Poland (Birkenmajer et al. 2002). Other lava flows crop out at Čedičový vrch Hill near the village Zálesí in the Czech Republic. At these localities, large xenoliths of spinel lherzolite, harzburgite and dunite occur, accompanied by rare clinopyroxenite xenoliths and orthopyroxene megacrysts (Fediuk and Fediuková 1989; Matusiak-Małek et al. 2010). K-Ar ages of samples from the volcanic plug at Lutynia I and Lutynia II are $4.56 \pm 0.20$ and $3.83 \pm 0.17 \mathrm{Ma}$, respectively, and the Lądek Zdrój flows yielded 5.46 $\pm 0.23 \mathrm{Ma}$ (Birkenmajer et al. 2002). Spinel lherzolite and harzburgite xenoliths (of angular to oval shape, up to $10 \mathrm{~cm}$ in size) with rare amphibole were studied in detail by Matusiak-Małek et al. (2010). These authors reported evidence for different degrees of partial melting (8-15\%) and subsequent cryptic metasomatism by a $\mathrm{CO}_{2}$-bearing alkaline melt. Pyroxenite xenoliths have not been described previously from this locality.

\section{Analytical methods}

Major-element analyses of minerals in the studied pyroxenite samples were carried out at the Institute of Geology v.v.i., Academy of Sciences of the Czech Republic, Prague (ASCR), on a CAMECA SX 100 electron microprobe (EMP) equipped with a WDS analyzer. Analytical conditions were $15 \mathrm{kV}$ accelerating voltage, $10 \mathrm{nA}$ current and $2 \mu \mathrm{m}$ beam diameter. The bulk compositions of symplectite pseudomorphs after garnet were analyzed using a larger beam diameter of $80 \mu \mathrm{m}$. Synthetic and natural minerals were used as internal standards for corresponding elements and data reduction was performed by the software of Merlet (1994). The mineral abbreviations used in this work are from Kretz (1983).

Trace-element concentrations in clinopyroxene and symplectite pseudomorphs were determined in-situ using a Thermo-Finnigan Element 2 sector field ICP-MS coupled with a $213 \mathrm{~nm}$ NdYAG laser (New Wave Research UP-213) at ASCR. The laser was fired at a repetition rate of $20 \mathrm{~Hz}$, the laser energy was $6-7 \mathrm{~J} / \mathrm{cm}^{2}$, and the 100 $\mu \mathrm{m}$ beam size produced $60 \mu \mathrm{m}$-long ablation line patterns. One to two analyses were performed in individual clinopyroxene grains or symplectite pseudomorphs. The sample introduction system was modified to enable the simultaneous nebulization (e.g., Horn et al. 2000) of a tracer solution through an Aridus $\mathrm{II}^{\mathrm{TM}}$ desolvating nebulizer (CETAC Technologies) and a T-piece tube attached to the back end of the plasma torch. All isotopes were measured at the low mass resolution mode $(\mathrm{m} / \Delta \mathrm{m}=300)$ and the data were calibrated against the external standard of synthetic silicate glass NIST SRM 612. The internal standardization with ${ }^{40} \mathrm{Ca}$ was used to correct for matrix effects and signal drift of the ICP-MS. The time-resolved signal data were processed using the Glitter software (http://www.glitter-gemoc.com/) and the absolute concentrations were calculated using Pearce et al. (1997) values for NIST 612. The analytical precision (relative standard deviation - RSD) of all elements is better than $5 \%$. The accuracy was tested using cross calibration between NIST SRM 610 and 612 glasses yielding RSDs better than 10\% for most analyzed elements when compared to published values (Pearce et al. 1997).

The Sr-Nd isotopic analyses of clinopyroxene separates from the xenolith samples were performed at the Universität München according to the procedures outlined in Hegner et al. (1995). In order to remove grain boundary components, the minerals were leached in hot $6 \mathrm{M} \mathrm{HCl}$ and $6 \mathrm{M} \mathrm{HNO}_{3}$ for one hour each, followed by washing them three times in ultrapure water. The Sr and Nd isotopic abundances were acquired by ThermoFisher Triton thermal ionization mass spectrometer in static mode. The ${ }^{143} \mathrm{Nd} /{ }^{144} \mathrm{Nd}$ ratios were normalized to ${ }^{146} \mathrm{Nd} /{ }^{144} \mathrm{Nd}=0.7219$ using an exponential fractionation law. The $\mathrm{Nd}$ reference material JNdi-1 analyzed during this study yielded ${ }^{143} \mathrm{Nd} /{ }^{144} \mathrm{Nd}=0.512095 \pm 6$ ( 2 sigma, $\mathrm{n}=3$ ) and the measured ratios were adjusted for machine bias to our high-precision measurements of ${ }^{143} \mathrm{Nd} /{ }^{144} \mathrm{Nd}=0.512102 \pm 1$ for this material (Jochum et al. 2010). The $\varepsilon_{\mathrm{Nd}}$ values were calculated with the present-day values for the chondrite uniform reservoir (CHUR): ${ }^{147} \mathrm{Sm} /{ }^{144} \mathrm{Nd}=0.1960$ and ${ }^{143} \mathrm{Nd} /{ }^{144} \mathrm{Nd}=$ 0.512630 of Bouvier et al. (2008). The ${ }^{87} \mathrm{Sr} /{ }^{86} \mathrm{Sr}$ ratios were normalized to ${ }^{86} \mathrm{Sr} /{ }^{88} \mathrm{Sr}=0.1194$. The NIST 987 reference material yielded ${ }^{87} \mathrm{Sr} /{ }^{86} \mathrm{Sr}=0.710246 \pm 8$ (2 sigma, $\mathrm{n}=3$ ).

Data handling and plotting was carried out using the GCDkit software (Janoušek et al. 2006).

\section{Petrography and microstructure of the pyroxenite xenoliths}

The Kozákov pyroxenite xenoliths include two websterites, samples KOZ-4 and KOZ-5, and one olivine clinopyroxenite, KOZ-17, which were collected in an active quarry near the village of Proseč. Samples KOZ4 and KOZ-5 are rounded xenoliths of $6 \times 7 \mathrm{~cm}$ in size, whereas sample KOZ-17 is a subangular xenolith of $4 \times 4 \mathrm{~cm}$ across. The xenoliths exhibit distinctly different textures (following the classification of Mercier and Nicolas, 1975) and petrographic features.

Sample KOZ-4 is a websterite (Tab. 1) with a porphyroclastic texture, in which large, strained grains of clinopyroxene up to $2 \mathrm{~cm}$ are surrounded by a matrix of fine-grained $(0.5-2 \mathrm{~mm})$ anhedral grains of undeformed orthopyroxene and clinopyroxene (Fig. 2a-b). Discrete interstitial grains, or inclusions, of brown 
Tab. 1 Summary of studied samples together with their main petrographic features

\begin{tabular}{|c|c|c|c|c|c|c|c|c|c|c|}
\hline \multirow[t]{2}{*}{ Sample } & \multirow[t]{2}{*}{ Locality } & \multirow[t]{2}{*}{ Rock type } & \multirow[t]{2}{*}{ Texture } & \multirow[t]{2}{*}{ \#Mg Cpx } & \multicolumn{4}{|c|}{ Modal composition (vol. \%) } & \multicolumn{2}{|c|}{ GPS location } \\
\hline & & & & & Cpx & Opx & Spl/symp & $\mathrm{Ol}$ & Longitude (E) & Latitude $(\mathrm{N})$ \\
\hline KOZ-4 & Kozákov & Websterite & Porphyroclastic & 90.0 & 80 & 15 & 5 & 0 & $15^{\circ} 17^{\prime} 25^{\prime \prime}$ & $50^{\circ} 37^{\prime} 18^{\prime \prime}$ \\
\hline KOZ-5 & Kozákov & Websterite & Protogranular & 89.5 & 75 & 28 & 2 & 0 & $15^{\circ} 17^{\prime} 25^{\prime \prime}$ & $50^{\circ} 37^{\prime} 18^{\prime \prime}$ \\
\hline KOZ-17 & Kozákov & Olivine clinopyroxenite & Equigranular & 92.8 & 90 & 3 & 2 & 5 & $15^{\circ} 17^{\prime} 25^{\prime \prime}$ & $50^{\circ} 37^{\prime} 18^{\prime \prime}$ \\
\hline DOB-07 & Dobkovičky & Websterite & Cumulate & 89.4 & 90 & 10 & 0 & 0 & $14^{\circ} 00^{\prime} 38^{\prime \prime}$ & $50^{\circ} 33^{\prime} 54^{\prime \prime}$ \\
\hline KUZ-3 & Kuzov & Olivine websterite & Equigranular & 91.3 & 81 & 15 & 1 & 3 & $13^{\circ} 54^{\prime} 12^{\prime \prime}$ & $50^{\circ} 28^{\prime} 30^{\prime \prime}$ \\
\hline LUT-2 & Lutynia & Websterite & Protogranular & 91.3 & 82 & 15 & 3 & 0 & $16^{\circ} 54^{\prime} 42^{\prime \prime}$ & $50^{\circ} 21^{\prime} 35^{\prime \prime}$ \\
\hline
\end{tabular}

$\# \mathrm{Mg}=100 \times\left[\mathrm{Mg} /\left(\mathrm{Mg}+\mathrm{Fe}^{2+}\right)\right]$; modal composition based on visual estimate
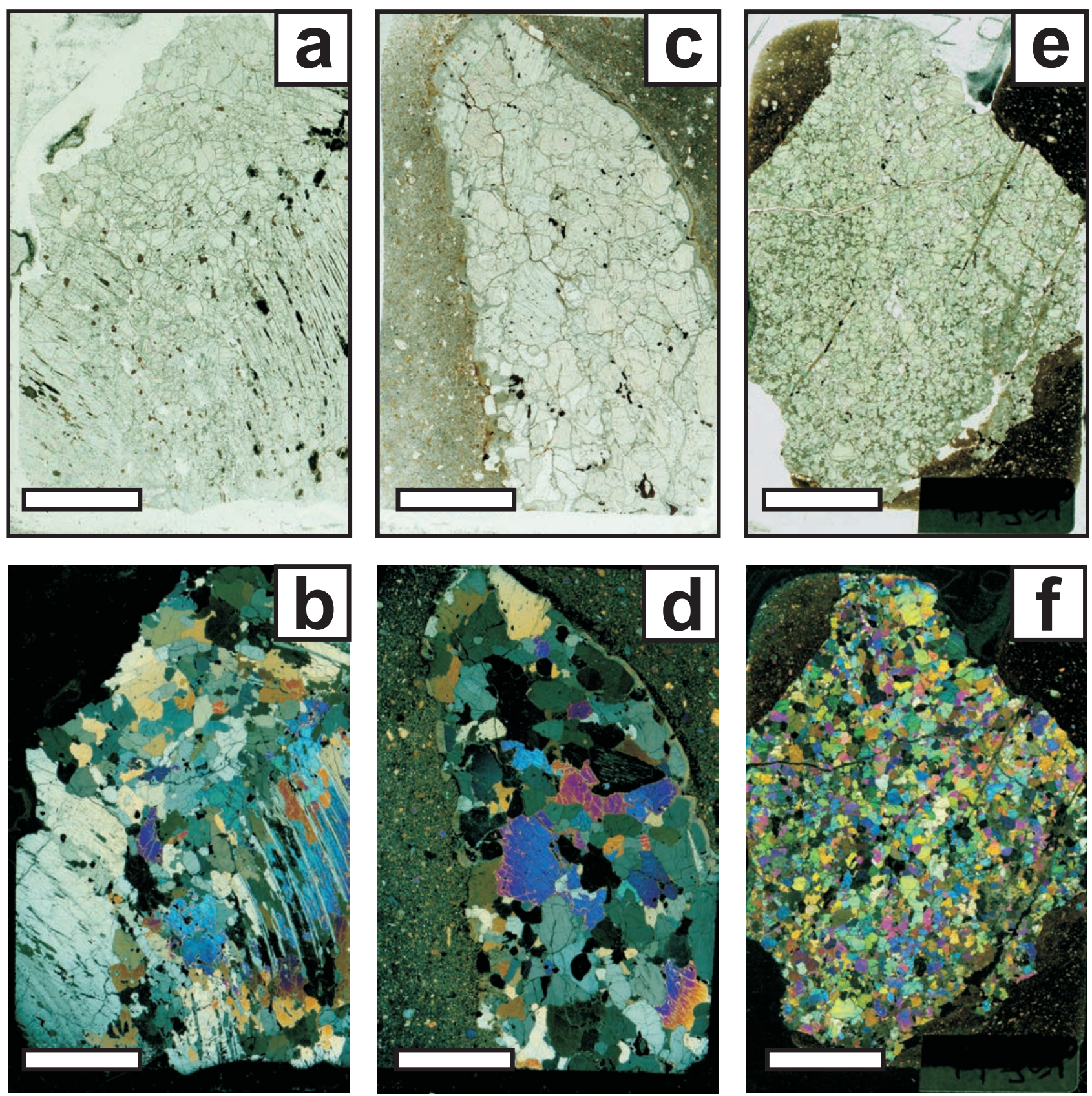

Fig. 2 Photomicrographs of pyroxenite xenoliths from Kozákov (plane polarized light and cross polarizers, respectively): spinel websterites KOZ-4 (a-b). KOZ-5 (c-d) and spinel-olivine-bearing clinopyroxenite KOZ-17 (e-f). Scale bar represents $1 \mathrm{~cm}$. 

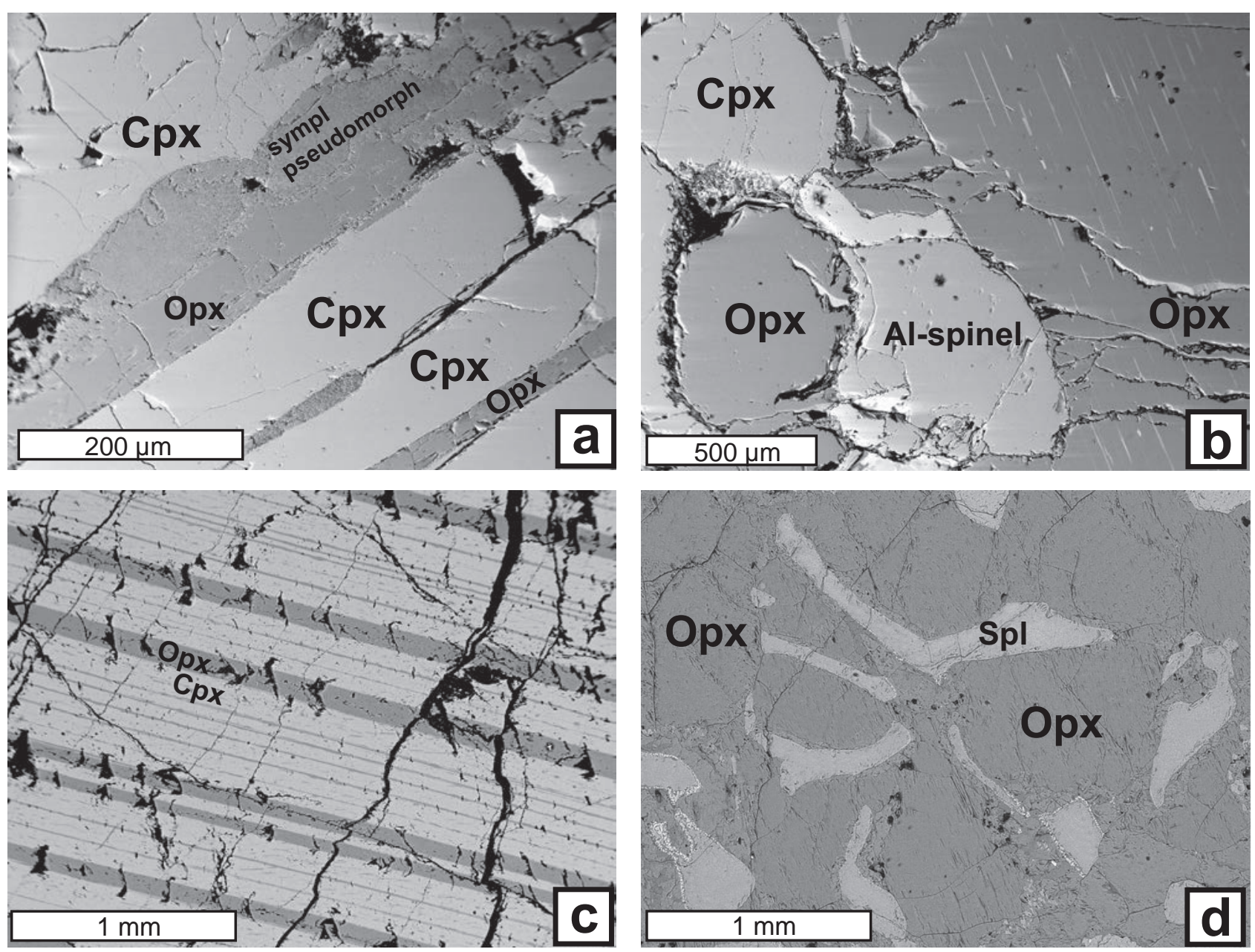

Fig. 3 Back-scattered electron (BSE) images illustrating important petrographic features of the studied xenoliths. a - Clinopyroxene porphyroclast with orthopyroxene lamellae associated with symplectite pseudomorph after garnet (KOZ-4). b - Protogranular texture, spinel rods and clinopyroxene exsolution lamellae within orthopyroxene (KOZ-5). c - Orthopyroxene exsolution lamellae within large clinopyroxene porphyroclast (DOB-07). d - Cr-spinel and orthopyroxene intergrowths in Lutynia websterite (LUT-2).

spinel, $<0.5 \mathrm{~mm}$ in size, occur in the matrix, as does rare ilmenite. The large clinopyroxene grains contain exsolution lamellae of orthopyroxene and symplectites interpreted as pseudomorphs after garnet. Symplectite pseudomorphs consist of orthopyroxene and plagioclase and occur as (1) lamellae $<1.5 \mathrm{~mm}$ in length parallel to either (100) or (010) in clinopyroxene (Fig. 3a), and (2) round to oval-shaped domains, $<1 \mathrm{~mm}$ across, within the matrix and porphyroclasts (Fig. 4a). In both cases, two textural varieties of symplectite can be distinguished: Type I with a smaller grain size and more pronounced layered structure, and a coarser-grained Type II (Fig. 4a-b). The grain sizes in both Type I ( $\leq 1$ $\mu \mathrm{m})$ and II $(1-3 \mu \mathrm{m})$ are too small to permit accurate chemical analysis by EMP. Oval-shaped pseudomorph domains also commonly contain kelyphite rims consisting of brown (Al-rich) spinel and orthopyroxene. The presence of melt pockets (olivine + plagioclase) at silicate grain boundaries in the xenolith is due to incipient, local melting of the xenolith in response to heating by basanite melt during incorporation and/or transport of the xenolith.

Sample KOZ-5 is a spinel websterite that exhibits a coarse-grained (2-6 mm grain size), protogranular texture (Fig. 2c-d). Pale Al-rich spinel occurs as small ( $\leq 0.5 \mathrm{~mm}$ in size), rounded grains at pyroxene grain boundaries and, locally, as inclusions. Orthopyroxene grains commonly contain preferentially oriented, tiny rods of spinel and thin exsolution lamellae of clinopyroxene (Fig. 3b).

Sample KOZ-17 is an olivine-spinel clinopyroxenite with a mosaic inequigranular texture, consisting of large $(1 \mathrm{~mm})$ clinopyroxene grains surrounded by a finer grained $(<0.5 \mathrm{~mm})$ clinopyroxene-rich matrix with curvilinear grain boundaries (Fig. 2e-f). The sample consists of $\sim 90$ vol. \% clinopyroxene, generally devoid of exsolution lamellae, and minor orthopyroxene and olivine, which are associated with larger clinopyroxene crystals. 


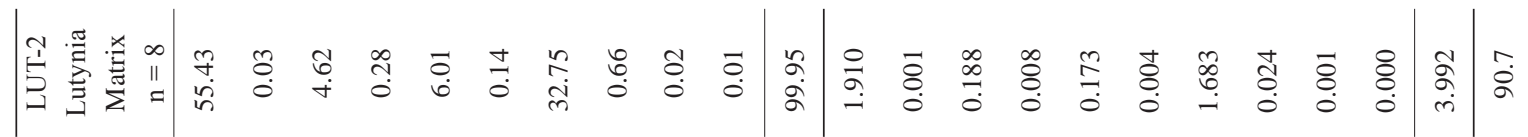

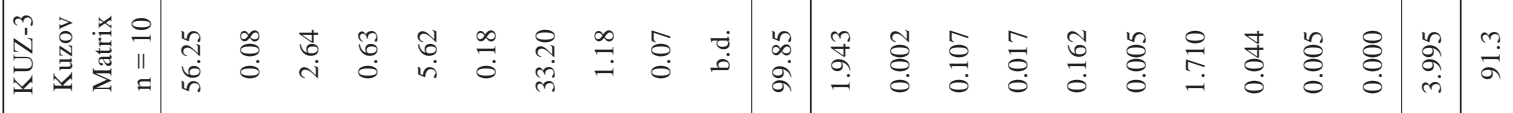

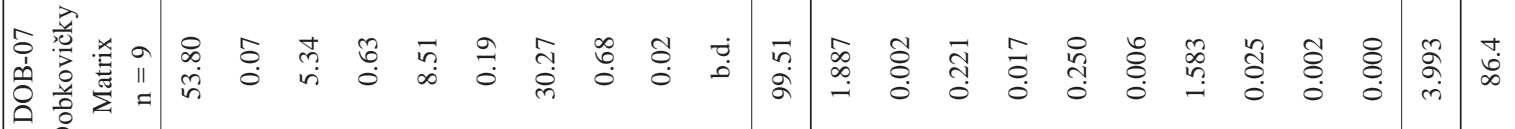

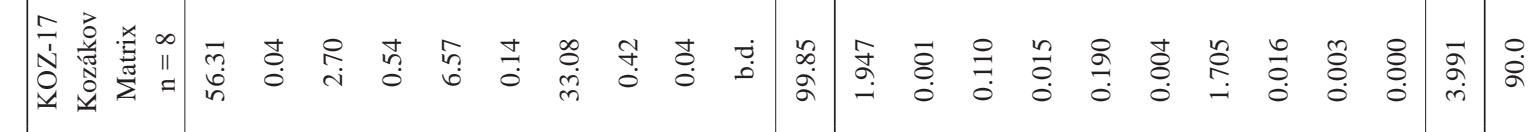

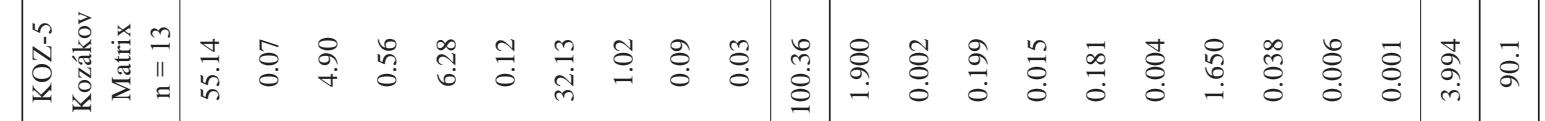

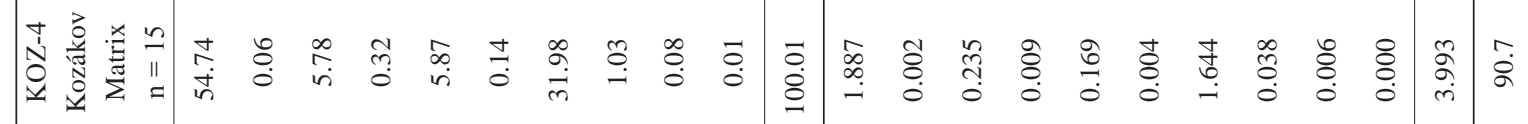


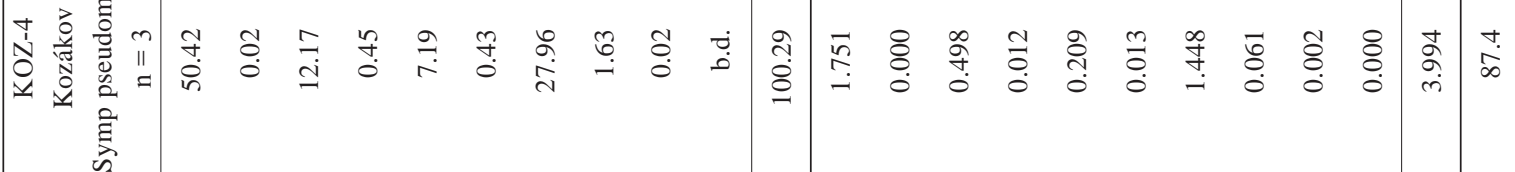

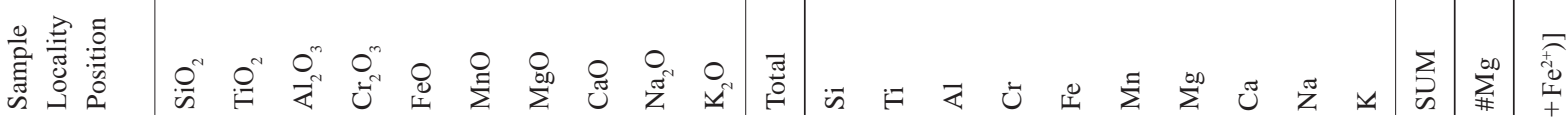

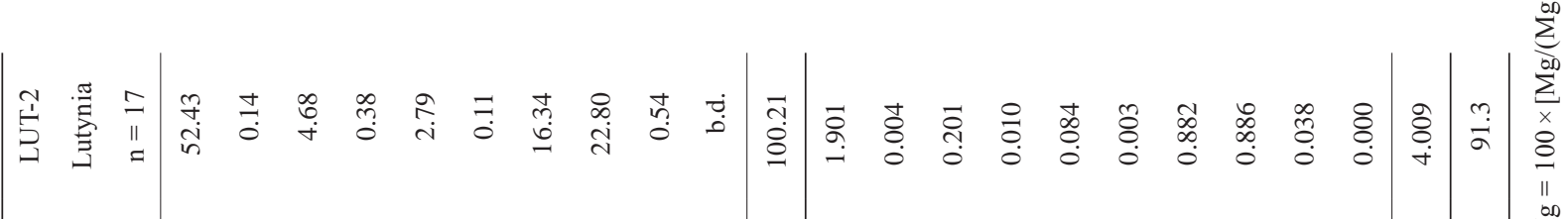

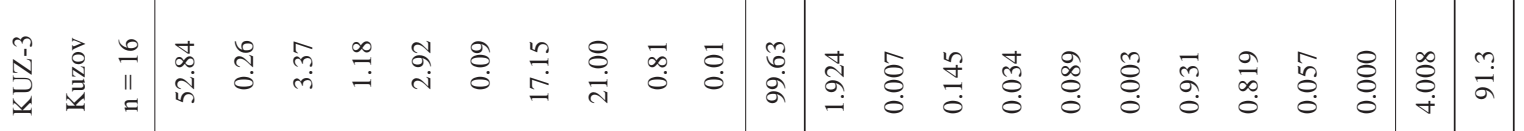

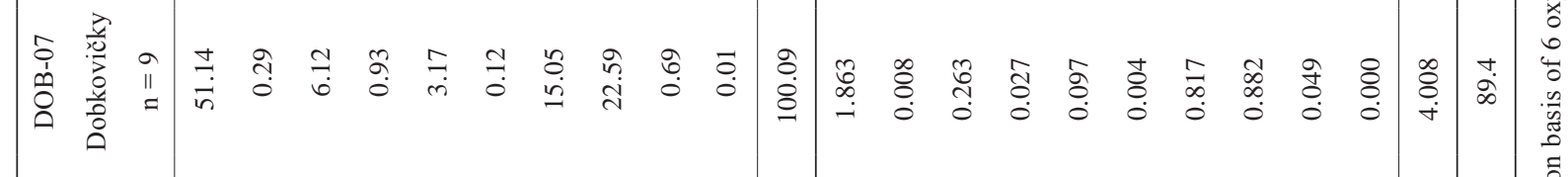

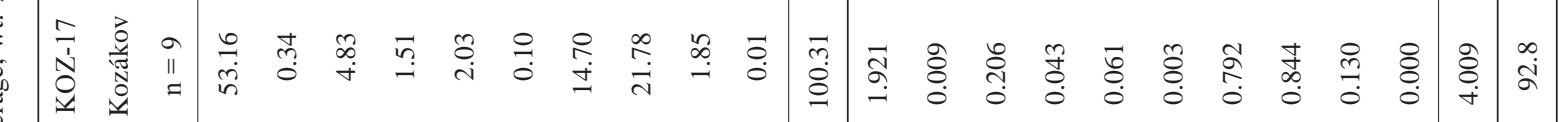

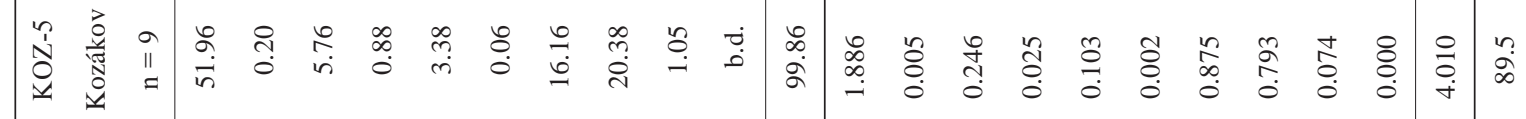

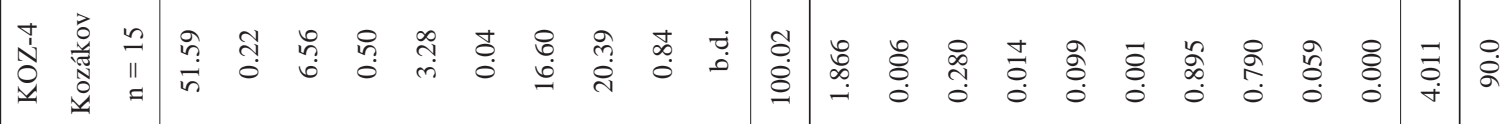

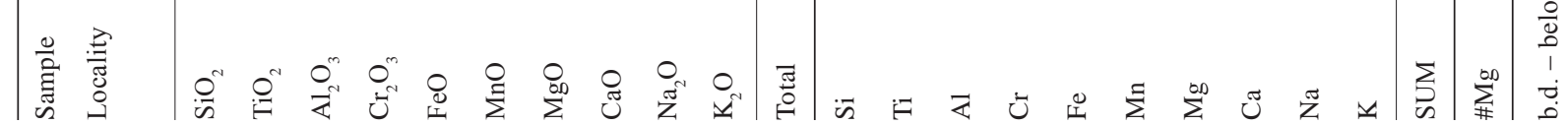



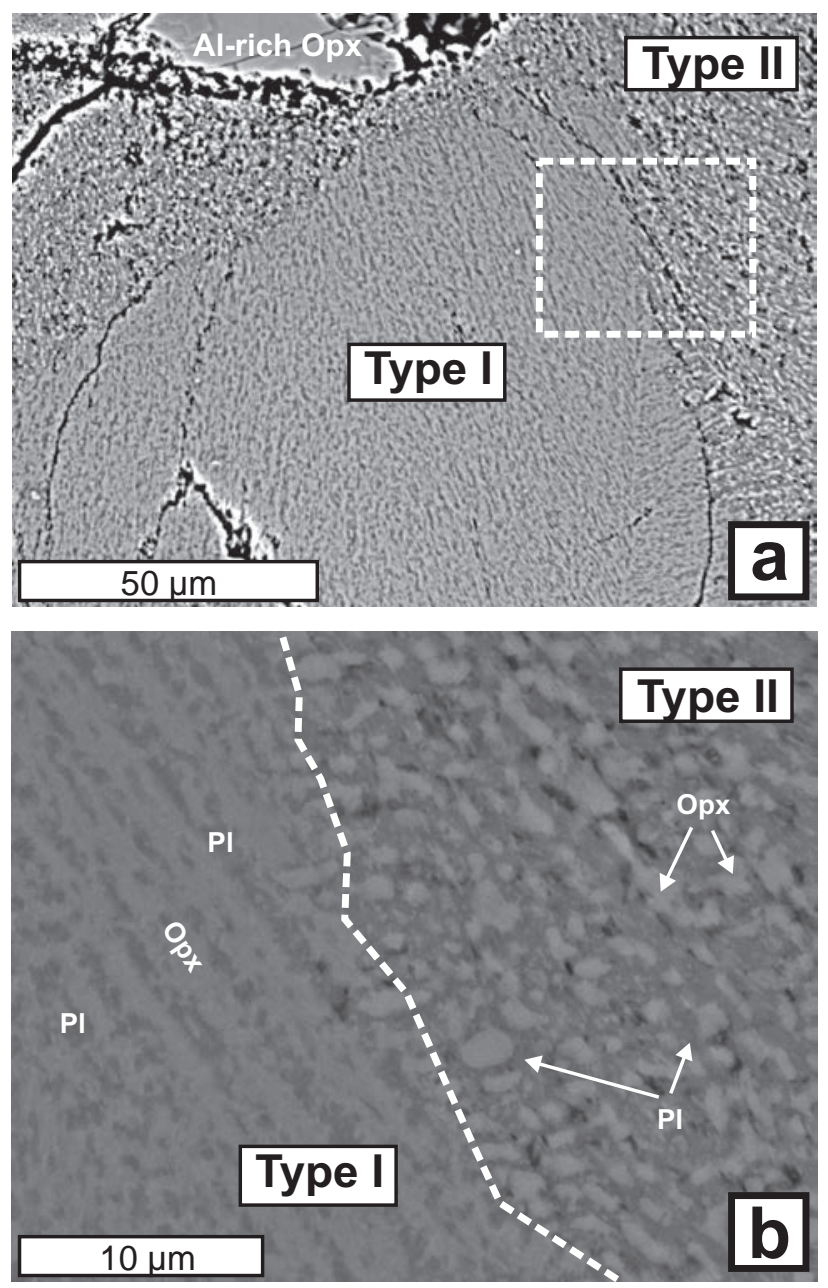

Fig. 4 Back-scattered electron (BSE) images of symplectite pseudomorphs after garnet in Kozákov websterite KOZ-4. a - Two texturally and chemically distinct types (I and II) accompanied by Al-rich orthopyroxene. $\mathbf{b}$ - Detailed image (dashed-line box in image a) of the contact between types I and II.

Spinel occurs as light brown, irregular to rounded grains within the recrystallized matrix.

The Dobkovičky websterite sample DOB-07 has a rounded shape with a dimension $4 \times 4 \mathrm{~cm}$ and contains an entirely fresh mineral assemblage. The xenolith shows a characteristic, magmatic cumulate texture (Fig. 5a-b), in which large clinopyroxene grains up to $2 \mathrm{~cm}$ in size represent the cumulus phase, with the interstitial areas being occupied by intercumulus orthopyroxene grains $1-2 \mathrm{~mm}$ in size. Orthopyroxene also occurs as $\leq 50 \mu \mathrm{m}$ wide exsolution lamellae within large clinopyroxene grains (Fig. 3c). Both phases are free of strain. Spinel is absent in this xenolith.

The Kuzov olivine websterite KUZ-3 (oval-shaped and $\sim 3 \mathrm{~cm}$ in size) exhibits an equigranular texture with a grain size of 0.5 to $1 \mathrm{~mm}$ (Fig. $5 \mathrm{c}-\mathrm{d}$ ). The sample contains clinopyroxene, orthopyroxene, and serpentinized olivine. Clinopyroxene contains abundant orthopyroxene
Tab. 4 Major-element composition (average, wt. \%) of spinel from studied pyroxenites

\begin{tabular}{|c|c|c|c|c|c|}
\hline Sample & KOZ-4 & KOZ-5 & KOZ-17 & DOB-07 & LUT-2 \\
\hline Locality & $\begin{array}{c}\text { Kozákov } \\
\mathrm{n}=6\end{array}$ & $\begin{array}{c}\text { Kozákov } \\
\mathrm{n}=17\end{array}$ & $\begin{array}{c}\text { Kozákov } \\
\mathrm{n}=2\end{array}$ & $\begin{array}{c}\text { Dobkovičky } \\
\mathrm{n}=2\end{array}$ & $\begin{array}{c}\text { Lutynia } \\
\mathrm{n}=3\end{array}$ \\
\hline $\mathrm{TiO}_{2}$ & 0.05 & 0.16 & 0.05 & 0.40 & 0.04 \\
\hline $\mathrm{Al}_{2} \mathrm{O}_{3}$ & 62.36 & 50.15 & 39.79 & 50.96 & 59.69 \\
\hline $\mathrm{Cr}_{2} \mathrm{O}_{3}$ & 4.76 & 16.16 & 28.64 & 14.85 & 6.59 \\
\hline $\mathrm{V}_{2} \mathrm{O}_{5}$ & 0.03 & 0.06 & 0.11 & 0.49 & 0.06 \\
\hline $\mathrm{FeO}$ & 9.46 & 12.93 & 13.99 & 13.36 & 10.92 \\
\hline $\mathrm{MnO}$ & 0.07 & b.d. & b.d. & b.d. & b.d. \\
\hline $\mathrm{MgO}$ & 21.68 & 19.79 & 16.10 & 18.65 & 21.26 \\
\hline $\mathrm{CaO}$ & 0.07 & 0.01 & 0.00 & 0.04 & 0.02 \\
\hline $\mathrm{ZnO}$ & 0.01 & b.d. & 0.18 & 0.08 & 0.07 \\
\hline $\mathrm{NiO}$ & 0.23 & 0.37 & 0.29 & 0.20 & 0.32 \\
\hline Total & 98.71 & 99.62 & 99.15 & 99.03 & 98.96 \\
\hline$\overline{\mathrm{Ti}}$ & 0.001 & 0.003 & 0.001 & 0.008 & 0.001 \\
\hline $\mathrm{Al}$ & 1.870 & 1.574 & 1.330 & 1.613 & 1.807 \\
\hline $\mathrm{Cr}$ & 0.096 & 0.340 & 0.643 & 0.315 & 0.134 \\
\hline V & 0.001 & 0.001 & 0.003 & 0.011 & 0.001 \\
\hline $\mathrm{Fe}^{3+}$ & 0.032 & 0.082 & 0.023 & 0.054 & 0.057 \\
\hline Total & 2.000 & 2.000 & 2.000 & 2.000 & 2.000 \\
\hline $\mathrm{Fe}^{2+}$ & 0.169 & 0.206 & 0.309 & 0.246 & 0.177 \\
\hline Mn & 0.002 & 0.000 & 0.000 & 0.000 & 0.000 \\
\hline Mg & 0.823 & 0.786 & 0.681 & 0.747 & 0.814 \\
\hline $\mathrm{Ca}$ & 0.002 & 0.000 & 0.000 & 0.001 & 0.000 \\
\hline $\mathrm{Zn}$ & 0.000 & 0.000 & 0.004 & 0.002 & 0.001 \\
\hline $\mathrm{Ni}$ & 0.005 & 0.008 & 0.007 & 0.004 & 0.007 \\
\hline Total & 1.000 & 1.000 & 1.000 & 1.000 & 1.000 \\
\hline \#Mg & 82.9 & 79.2 & 68.8 & 75.2 & 82.1 \\
\hline \#Cr & 4.9 & 17.8 & 32.6 & 16.4 & 6.9 \\
\hline
\end{tabular}

b.d. - below detection limit. Cations calculated on basis of 3 cations. $\# \mathrm{Mg}=100 \times\left[\mathrm{Mg} /\left(\mathrm{Mg}+\mathrm{Fe}^{2+}\right)\right], \# \mathrm{Cr}=100 \times[\mathrm{Cr} /(\mathrm{Cr}+\mathrm{Al})]$

Tab. 5 Major-element composition (average, wt. \%) of olivine from studied pyroxenites

\begin{tabular}{lcc}
\hline Sample & KOZ-17 & KUZ-3 \\
Kozality & $\mathrm{n}=3$ & $\mathrm{Kuzov}$ \\
& 40.71 & $\mathrm{n}=2$ \\
\hline $\mathrm{SiO}_{2}$ & 9.95 & 40.72 \\
$\mathrm{FeO}$ & 0.19 & 9.25 \\
$\mathrm{MnO}$ & 48.17 & 0.16 \\
$\mathrm{MgO}$ & 0.04 & 48.86 \\
$\mathrm{CaO}$ & 0.41 & 0.11 \\
$\mathrm{NiO}$ & 99.48 & 0.28 \\
\hline $\mathrm{Total}$ & 0.998 & 99.38 \\
\hline $\mathrm{Si}$ & 0.207 & 0.996 \\
$\mathrm{Fe}{ }^{2+}$ & 0.004 & 0.192 \\
$\mathrm{Mn}$ & 1.784 & 0.003 \\
$\mathrm{Mg}$ & 0.001 & 1.805 \\
$\mathrm{Ca}$ & 0.008 & 0.003 \\
$\mathrm{Ni}$ & 3.002 & 0.006 \\
\hline Total & 89.6 & 3.004 \\
\hline$\# \mathrm{Mg}$ & & 90.4 \\
\hline
\end{tabular}

Cations calculated on basis of 4 oxygens. $\# \mathrm{Mg}=100 \times\left[\mathrm{Mg} /\left(\mathrm{Mg}+\mathrm{Fe}^{2+}\right)\right]$ 

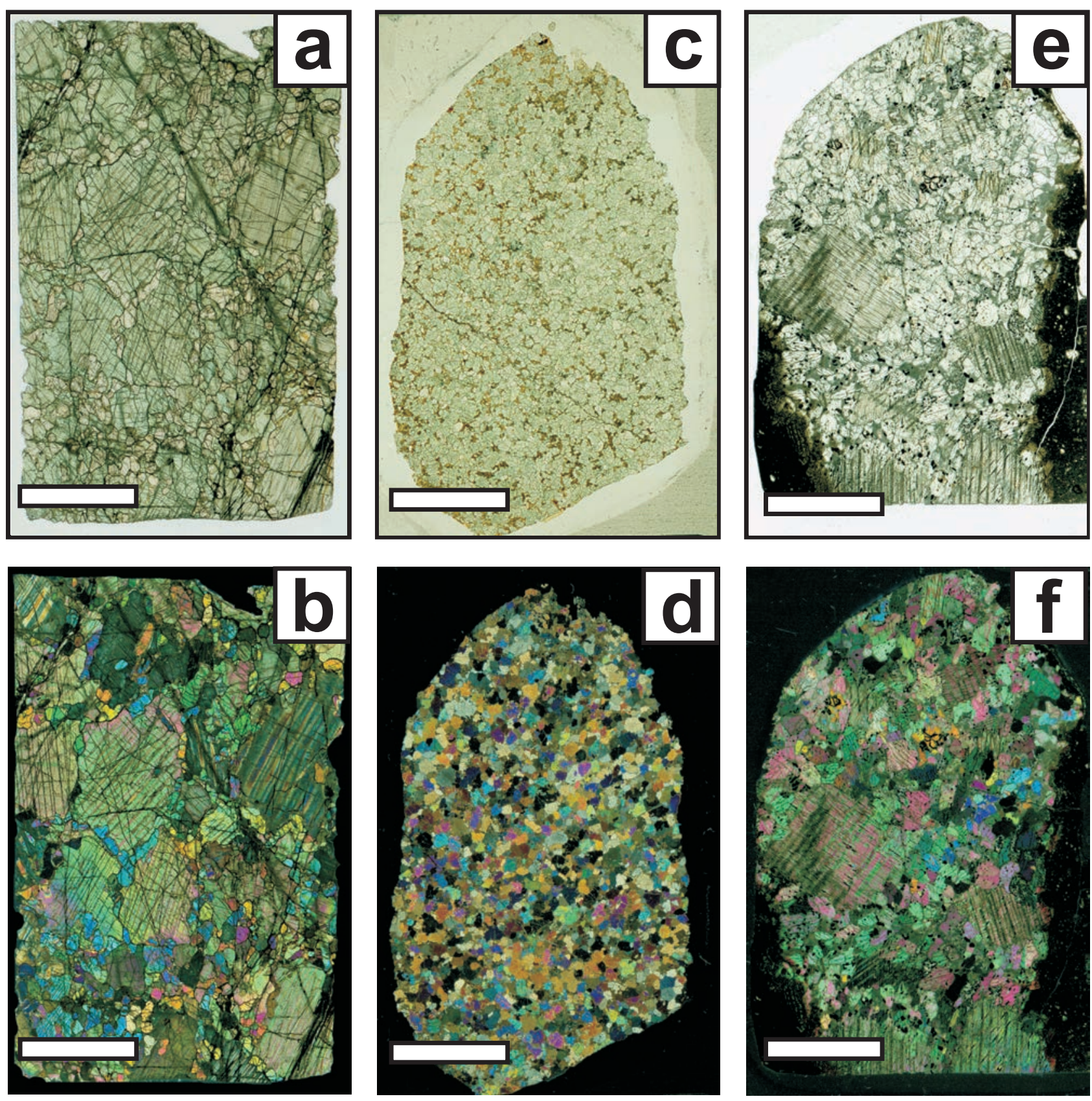

Fig. 5 Photomicrographs of pyroxenite xenoliths (plane polarized light and cross polarizers, respectively): spinel websterite DOB-07 (Dobkovičky; a-b), spinel-olivine websterite KUZ-3 (Kuzov; c-d) and spinel websterite LUT-2 (Lutynia; e-f). Scale bar represents $1 \mathrm{~cm}$.

exsolution lamellae, as well as rare light brown Al-rich rounded spinel inclusions.

The Lutynia spinel websterite LUT-2 was collected in the active quarry Lutynia II and has an oval shape with dimensions of approximately $4 \times 2 \mathrm{~cm}$. The sample has an inequigranular texture (Fig. 5e-f) with larger, 0.5 to $2 \mathrm{~cm}$, clinopyroxene grains in a finer, 0.5 to $4 \mathrm{~mm}$, matrix of tabular to anhedral clinopyroxene and orthopyroxene. Clinopyroxene encloses orthopyroxene and spinel exsolution lamellae. Spinel is common in the matrix and occurs in three textural varieties: (1) large interstitial equant Cr-rich grains, (2) "vermicular” Cr-rich grains in intergrowths with orthopyroxene (Fig. 3d), and (3) small, subequant, light brown $\mathrm{Al}$-rich grains enclosed in clinopyroxene or orthopyroxene.

\section{Mineral compositions}

All the studied pyroxenites consist of variable proportions of clinopyroxene and orthopyroxene, accompanied by accessory spinel and, in KOZ-17 and KUZ-3, by 
Tab. 6 Major-element compositions (average, wt. \%) of symplectite pseudomorphs from Kozákov websterite KOZ-4

\begin{tabular}{|c|c|c|c|c|c|c|c|c|}
\hline Domain & Type I & Type I & Type I & Type I & Type II & Type II & Type II & Type II \\
\hline $\mathrm{SiO}_{2}$ & 42.60 & 42.74 & 43.05 & 42.64 & 41.94 & 42.54 & 42.15 & 43.14 \\
\hline $\mathrm{TiO}_{2}$ & 0.05 & 0.07 & 0.05 & 0.06 & 0.06 & 0.06 & 0.06 & 0.15 \\
\hline $\mathrm{Al}_{2} \mathrm{O}_{3}$ & 22.97 & 23.52 & 23.43 & 23.23 & 23.05 & 23.87 & 23.80 & 25.17 \\
\hline $\mathrm{Cr}_{2} \mathrm{O}_{3}$ & 0.57 & 0.56 & 0.73 & 0.67 & 0.55 & 0.59 & 0.60 & 0.82 \\
\hline $\mathrm{FeO}$ & 6.69 & 6.32 & 6.73 & 6.53 & 5.66 & 5.92 & 5.85 & 5.17 \\
\hline $\mathrm{MnO}$ & 0.29 & 0.31 & 0.36 & 0.34 & 0.22 & 0.24 & 0.22 & 0.25 \\
\hline $\mathrm{MgO}$ & 22.30 & 20.85 & 21.20 & 21.49 & 19.41 & 19.06 & 18.05 & 16.15 \\
\hline $\mathrm{CaO}$ & 3.96 & 4.52 & 4.26 & 4.20 & 6.37 & 4.86 & 5.86 & 5.81 \\
\hline $\mathrm{Na}_{2} \mathrm{O}$ & 0.61 & 0.75 & 0.65 & 0.49 & 2.30 & 2.82 & 2.52 & 2.28 \\
\hline $\mathrm{K}_{2} \mathrm{O}$ & 0.05 & 0.07 & 0.05 & 0.06 & 0.19 & 0.41 & 0.30 & 0.24 \\
\hline Total & 100.09 & 99.70 & 100.52 & 99.71 & 99.75 & 100.36 & 99.41 & 99.17 \\
\hline$\overline{\mathrm{Si}}$ & 3.009 & 3.029 & 3.029 & 3.018 & 3.031 & 3.060 & 3.057 & 3.103 \\
\hline $\mathrm{Ti}$ & 0.003 & 0.004 & 0.003 & 0.003 & 0.003 & 0.003 & 0.003 & 0.008 \\
\hline $\mathrm{Al}$ & 1.912 & 1.965 & 1.943 & 1.938 & 1.963 & 2.023 & 2.035 & 2.134 \\
\hline $\mathrm{Cr}$ & 0.032 & 0.031 & 0.041 & 0.037 & 0.031 & 0.034 & 0.034 & 0.047 \\
\hline $\mathrm{Fe}$ & 0.395 & 0.375 & 0.396 & 0.387 & 0.342 & 0.356 & 0.355 & 0.311 \\
\hline $\mathrm{Mn}$ & 0.017 & 0.019 & 0.021 & 0.020 & 0.013 & 0.015 & 0.014 & 0.015 \\
\hline $\mathrm{Mg}$ & 2.348 & 2.203 & 2.224 & 2.268 & 2.091 & 2.044 & 1.952 & 1.732 \\
\hline $\mathrm{Ca}$ & 0.300 & 0.343 & 0.321 & 0.319 & 0.493 & 0.375 & 0.455 & 0.448 \\
\hline $\mathrm{Na}$ & 0.084 & 0.103 & 0.089 & 0.067 & 0.322 & 0.393 & 0.355 & 0.318 \\
\hline $\mathrm{K}$ & 0.005 & 0.006 & 0.005 & 0.005 & 0.018 & 0.038 & 0.028 & 0.022 \\
\hline Total & 8.105 & 8.078 & 8.070 & 8.063 & 8.309 & 8.340 & 8.288 & 8.138 \\
\hline \% Alm & 12.9 & 12.7 & 13.4 & 12.9 & 11.6 & 12.8 & 12.8 & 12.4 \\
\hline \% Sps & 0.6 & 0.6 & 0.7 & 0.7 & 0.5 & 0.5 & 0.5 & 0.6 \\
\hline \% Prp & 76.7 & 74.9 & 75.1 & 75.8 & 71.1 & 73.3 & 70.3 & 69.1 \\
\hline$\%$ Grs & 9.8 & 11.7 & 10.8 & 10.6 & 16.8 & 13.4 & 16.4 & 17.9 \\
\hline \#Mg & 85.6 & 85.5 & 84.9 & 85.4 & 85.9 & 85.2 & 84.6 & 84.8 \\
\hline
\end{tabular}

Cations calculated on basis of 12 oxygens. Alm - almandine, Sps - spessartine, Prp - pyrope, Grs - grossular.

$\# \mathrm{Mg}=100 \times\left[\mathrm{Mg} /\left(\mathrm{Mg}+\mathrm{Fe}^{2+}\right)\right]$

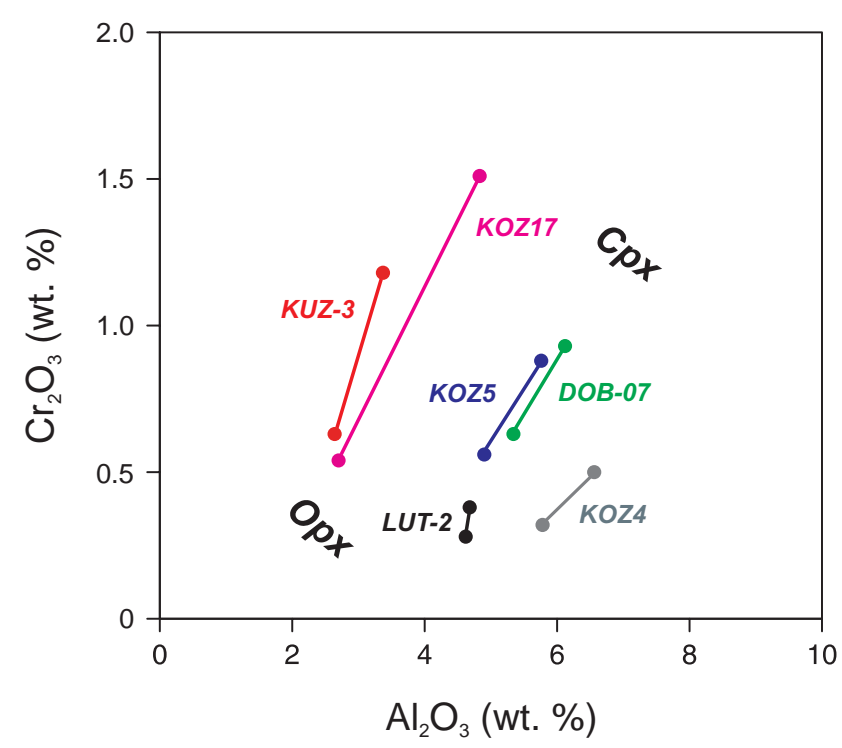

Fig. $6 \mathrm{Al}_{2} \mathrm{O}_{3}$ and $\mathrm{Cr}_{2} \mathrm{O}_{3}$ contents (wt. \%) of coexisting orthopyroxene and clinopyroxene.

olivine. In addition, sample KOZ-4 also contains symplectite pseudomorphs after garnet. Mineral compositions are given in Tabs $2-5$, and bulk compositions of the two different types of symplectite pseudomorphs (see above) in Tab. 6.

Clinopyroxene is relatively homogeneous in individual samples on the intra- and intergrain scales, with little difference between the compositions of cores and rims or porphyroclasts and matrix grains. $\mathrm{Mg}$ numbers (\#Mg $\left.=100 \times \mathrm{Mg} /\left[\mathrm{Mg}+\mathrm{Fe}^{2+}\right]\right)$ range from 89.4 to 92.8 , with the lowest values for DOB-07 websterite and the highest for KOZ-17 olivine clinopyroxenite. $\mathrm{Al}_{2} \mathrm{O}_{3}$ contents vary significantly among the samples, from $3.37 \mathrm{wt}$ \% for KUZ-3 websterite to 6.56 wt. \% for websterite KOZ-4. $\mathrm{Cr}_{2} \mathrm{O}_{3}$ contents also vary widely among the samples (0.38-1.51 wt. \%; Fig. 6). $\mathrm{Na}_{2} \mathrm{O}$ and $\mathrm{TiO}_{2}$ contents are low, (0.54-1.85 and 0.14-0.34 wt. \%, respectively).

Orthopyroxene, like clinopyroxene, is relatively homogeneous in composition on the inter- and intragrain scales. Mg numbers range from 86.4 to 91.3 among the samples, $\mathrm{CaO}$ contents from 0.42 to 1.18 wt. \%, and $\mathrm{Al}_{2} \mathrm{O}_{3}$ is highly variable between 2.64 to $5.78 \mathrm{wt}$ \%. The $\mathrm{Cr}_{2} \mathrm{O}_{3}$ and $\mathrm{Al}_{2} \mathrm{O}_{3}$ contents of both pyroxenes in the sample suite are plotted in Fig. 6, which illustrates the preference of clinopyroxene for $\mathrm{Al}$ and $\mathrm{Cr}$ over orthopyroxene, and the variable $\mathrm{Cr} / \mathrm{Al}$ ratios among samples, with KUZ-3 having the highest ratio and KOZ-4 the lowest. Orthopy- 
roxene associated with the symplectite pseudomorphs in Kozákov websterite KOZ-4 exhibits Al-rich compositions (average $\mathrm{Al}_{2} \mathrm{O}_{3}$ content of 12.17 wt. \%; Tab. 3), a relatively low $\mathrm{Mg}$ number of 87.4 and high $\mathrm{MnO}$ and $\mathrm{CaO}$ contents of 0.43 and $1.63 \mathrm{wt}$. \%, respectively.

Spinel shows a wide range in composition among the samples, with Mg numbers ranging from 68.8 to 82.9 and $\mathrm{Cr}$ numbers $(\# \mathrm{Cr}=100 \times \mathrm{Cr} /[\mathrm{Cr}+\mathrm{Al}])$ from 4.9 to 32.6 (Tab. 4; Fig. 7). Such values reflect the $\mathrm{Mg} / \mathrm{Fe}$ and $\mathrm{Cr} /$ $\mathrm{Al}$ ratios in the bulk pyroxenites and parallel those in pyroxenes, with the spinel richest in $\mathrm{Cr}$ occurring in sample $\mathrm{KOZ}-17$, and the spinel poorest in $\mathrm{Cr}$ in KOZ-4.

Olivine (Tab. 5) occurs only in Kozákov KOZ-17 $(\# \mathrm{Mg}=89.6)$ and Kuzov KUZ-3 $(\# \mathrm{Mg}=90.4) . \mathrm{NiO}$ contents are 0.41 wt. \% and 0.28 wt. \%, respectively, whereas $\mathrm{CaO}$ contents are 0.04 wt. $\%$ and 0.11 wt. \%.

The two types of symplectite pseudomorphs (types I and II) from Kozákov websterite KOZ-4 have different bulk compositions (Tab. 6). The very fine-grained Type I has a composition similar to that of a typical mantlederived garnet with \#Mg ranging from 84.9 to 85.6, $\mathrm{CaO}$ contents from 3.96 to 4.52 wt. \% and a pyrope component from 75 to $77 \mathrm{~mol} \%$. However, all analyses show elevated $\mathrm{Na}_{2} \mathrm{O}$ of 0.49 to $0.75 \mathrm{wt}$ \%. The Type II composition differs significantly from that of Type I in having much higher $\mathrm{Na}_{2} \mathrm{O}$ and $\mathrm{K}_{2} \mathrm{O}$ (2.28 to 2.82 wt. \% and 0.19 to 0.41 wt. \%, respectively), higher $\mathrm{CaO}$ (4.86 to 6.37 wt. \%), and a lower pyrope content (69 to 73 mol \%).

\section{Geothermobarometry}

Equilibration temperatures (Tab. 7a) for the studied xenoliths were calculated using three two-pyroxene and the Ca-in-orthopyroxene geothermometers (Bertrand and Mercier 1985; Brey and Köhler 1990; Taylor 1998) and a model pressure of 15 kbar. For sample KOZ-17

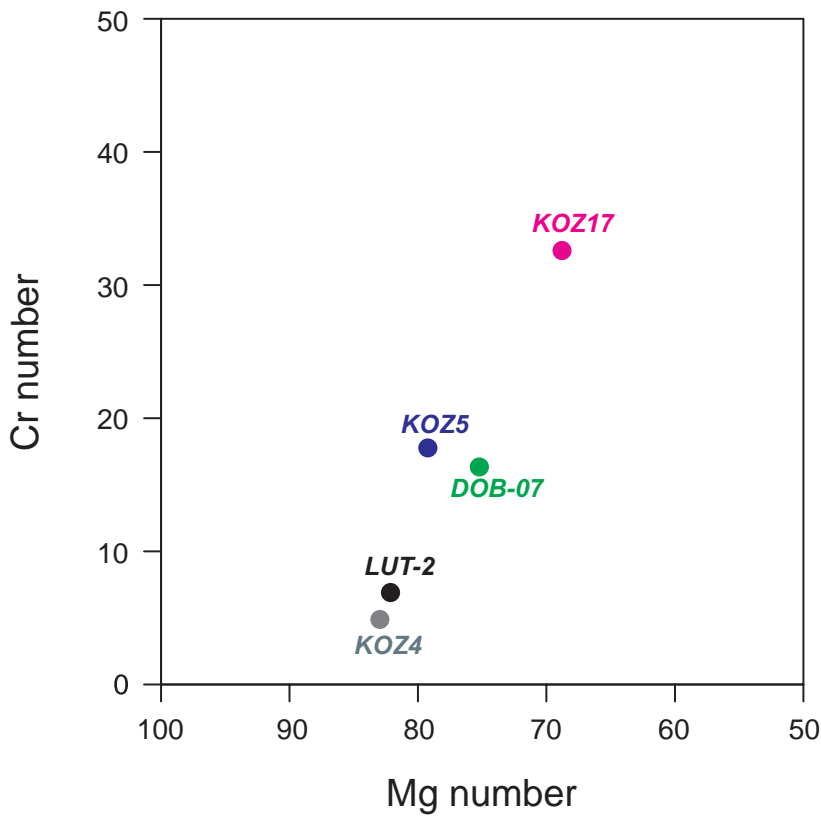

Fig. 7 Variation between Mg-number and $\mathrm{Cr}$-number in spinel from the studied samples.

containing spinel and olivine, the olivine-spinel $\mathrm{Mg}-\mathrm{Fe}$ thermometer of Ballhaus et al. (1991) was also employed. The pressure for websterite xenolith KOZ-4, which contains pseudomorphs after garnet, was calculated using the Al-in-Opx geobarometer of Brey and Köhler (1990) (Tab. 7b).

For most samples, the temperature estimates from the different geothermometers agree reasonably well (Tab. 7a). The Kozákov websterites KOZ-4 and KOZ5 exhibit similar, high temperatures of $1051-1102{ }^{\circ} \mathrm{C}$ and $1008-1067{ }^{\circ} \mathrm{C}$, respectively. The olivine-bearing websterite KUZ-3 yields similar temperature of $1020^{\circ} \mathrm{C}$ (two-pyroxene means). In contrast, the Dobkovičky and Lutynia websterites have much lower calculated temperatures of 841 and $881{ }^{\circ} \mathrm{C}$ (two-pyroxene means). The

Tab. 7a Equilibrium temperatures $\left({ }^{\circ} \mathrm{C}\right)$ of the studied xenoliths using various geothermometers

\begin{tabular}{|c|c|c|c|c|c|c|c|}
\hline Sample & Rock & Model P (kbar) & 2Px (BM85) & 2Px (BK90) & 2Px (T98) & $\mathrm{Ca}$ in Opx (BK90) & O1-Sp (B91) \\
\hline $\mathrm{KOZ}-4$ & Websterite & 15 & 1051 & 1102 & 1084 & 1063 & \\
\hline $\mathrm{KOZ}-5$ & Websterite & 15 & 1008 & 1067 & 1039 & 1061 & \\
\hline KOZ-17 & Olivine-bearing clinopyroxenite & 15 & 663 & 658 & 596 & 864 & 826 \\
\hline DOB- -07 & Websterite & 15 & 806 & 854 & 866 & 964 & \\
\hline KUZ-3 & Olivine-bearing websterite & 15 & 1000 & 1051 & 1008 & 1100 & \\
\hline LUT-2 & Websterite & 15 & 848 & 901 & 897 & 955 & \\
\hline
\end{tabular}

BM85 - Bertrand and Mercier (1985); BK90 - Brey and Köhler (1990); T98 - Taylor (1998); B91 - Ballhaus et al. (1991)

Tab. 7b Estimated temperatures, pressures, and depths for Kozákov websterite KOZ-4, using the composition of Type I symplectite

\begin{tabular}{llll}
\hline Methods & T, ${ }^{\circ} \mathrm{C}$ & P, kbar & depth, km \\
\hline BK90 T \& BK90 P & 1084 & 17.3 & 55.4 \\
H84 T \& BK90 P & 1199 & 21.4 & 68.5 \\
\hline
\end{tabular}

BK90 - Brey and Köhler (1990); H84 - Harley (1984) 


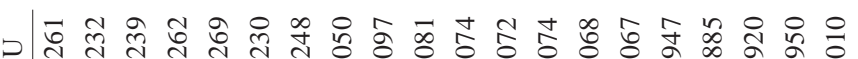

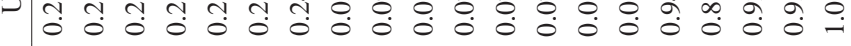
F苟导

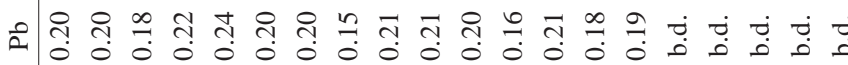

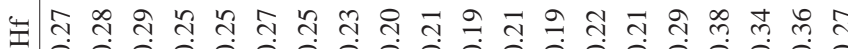

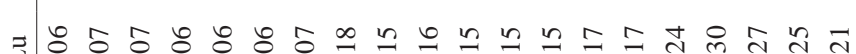

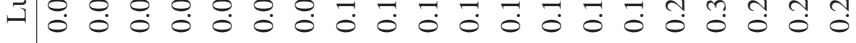

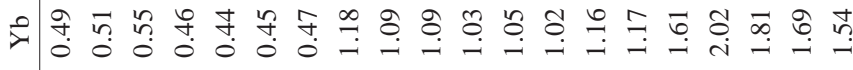
घ)

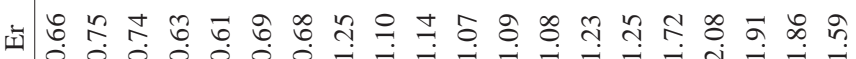

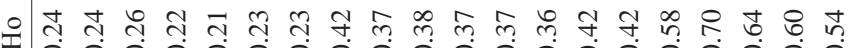

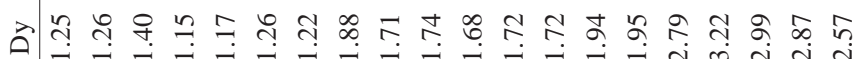

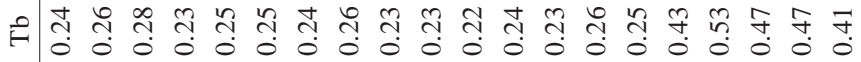
च ك =

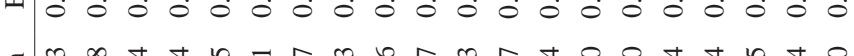

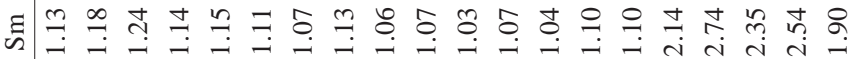

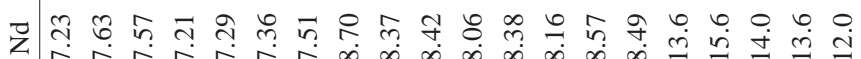
‡

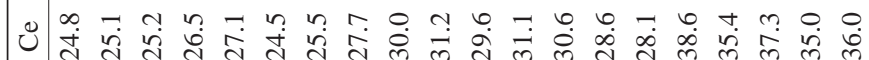

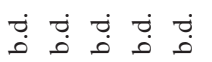

ف்ْ

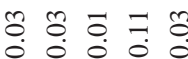

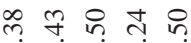

$0.0 \%$

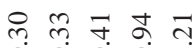

$0000 \%$

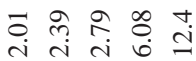

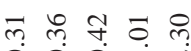

0 O 0 -

సี

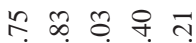

0 - 0 -

우 종 ำ

ๆ 马 ชู 孚

$\circ 00$ - ल

ఫ유요

i

芫串 츄

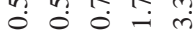

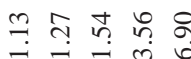

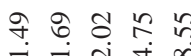

ป

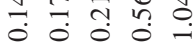

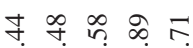

० 0 ० 0 -

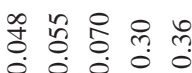

낭 승 의 웅

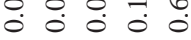

นด ดु

극ㄱㄱㅎㅇㅇㅇ

코늑 응

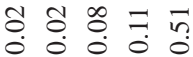

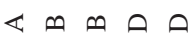

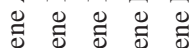

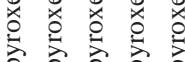

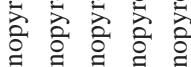

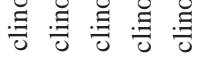

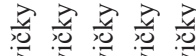

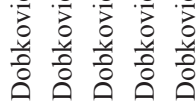

ㅎํㅇㅎㅇ

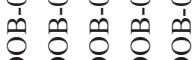

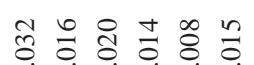

०० :0 : : : :

융용 भु

द: : : : : : :

웅 웅 웅 号

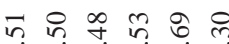

०० 0000

궁 $\%$ \& $\%$

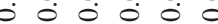

仓ํ

ㅇ \& \& \&

0.0000

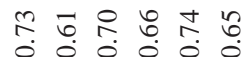

ฟิ ิสำ సิ

० 0 ० 0 ० 0

$\exists$ 눈

추느으응 능

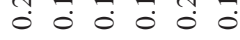

نْ

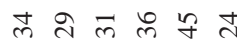

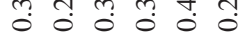

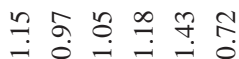

ริ กิ ๆ

$8000 \Omega$

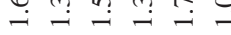

นึ

๑. 0 \% $\infty$

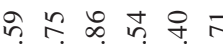

$\rightarrow 00000$

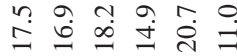

เ

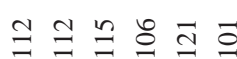

กิ

$\varangle \sqcap \backsim \cup \cap$

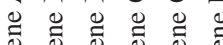

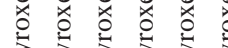

言言言言言言

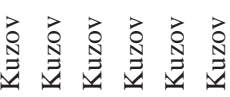

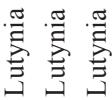

㑒望品

$\circ \quad 0 \quad 0$

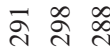

○े 0 ०

: : :

숭

$0 \begin{array}{lll}0 & 0 & 0 \\ 1 & 0 & 0\end{array}$

$\infty$

$\begin{array}{lll}0 & 0 & 0 \\ 0 & 0 & 0\end{array}$

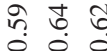

부응ㅇ

$\therefore 0$

잉충

$\circ 00$

齐岀

$\circ 00$

$\stackrel{\infty}{\longrightarrow}$ กิ

กิก สิ

$\therefore \sim$

국

ले

वे के

ㅇ. 요 न

$\infty 8 \infty$

$\dot{m}$ में

๑ œ ळ

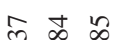

रें เ่ं เก

곡 $\stackrel{\infty}{i}$

꼬 글 늘

도. 느

욕

$\begin{array}{rll}-7 & 70\end{array}$

学

فํ.

$\varangle \infty \infty$

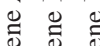

ํㅡㅇ

층

号.

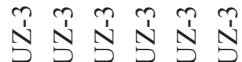

กิ 

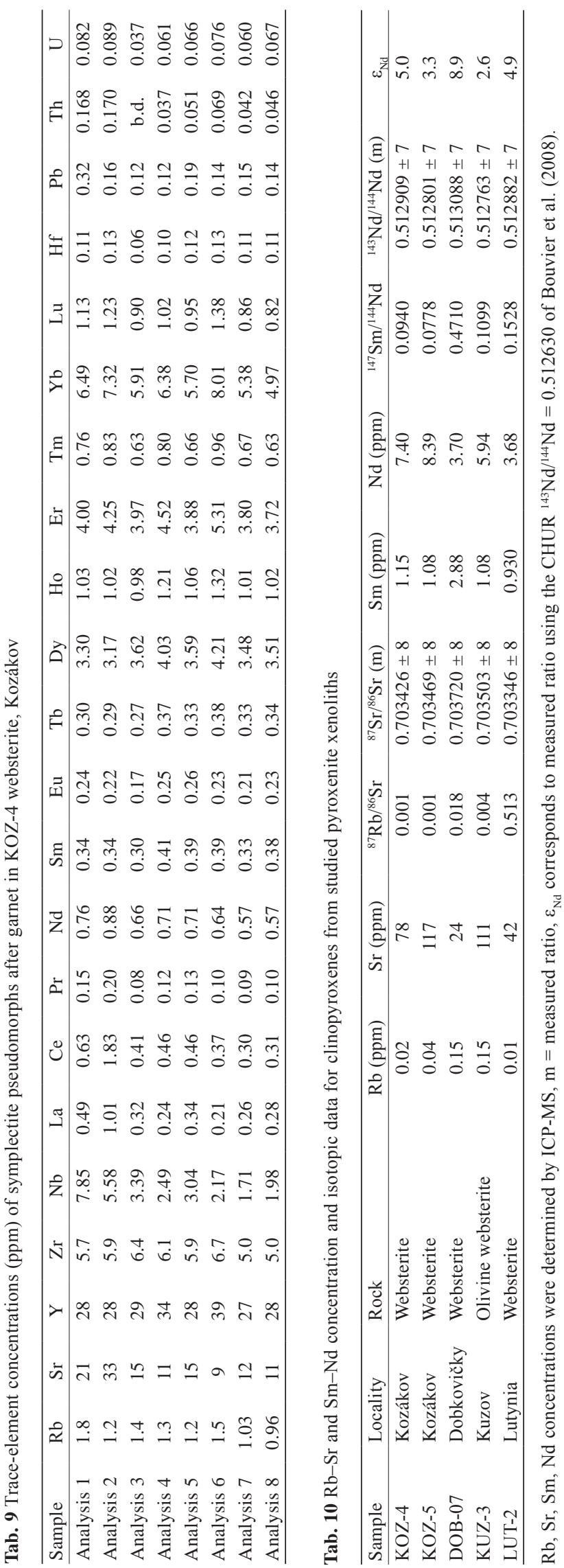

olivine clinopyroxenite KOZ-17 exhibits a still lower, mean two-pyroxene temperature range of $596-663{ }^{\circ} \mathrm{C}$, although the Ca-in-Opx and olivine-spinel thermometers yield 864 and $826{ }^{\circ} \mathrm{C}$ for this sample.

The bulk composition of Type I symplectite in websterite KOZ-4 resembles that of garnet, and assuming that the original, pre-symplectite garnet composition has been preserved, pressure has been calculated by the Al-in-Opx geobarometer (Brey and Köhler 1990) in combination with the two-pyroxene geothermometer (Brey and Köhler 1990) and the orthopyroxene-garnet Mg-Fe exchange geothermometer (Harley 1984) (Tab. 7b). This exercise has not been attempted for Type II symplectite because of its high $\mathrm{Na}_{2} \mathrm{O}$ and the unlikely preservation of the original garnet composition.

Iterative solution yields $1084{ }^{\circ} \mathrm{C} / 17.3 \mathrm{kbar}$ and 1199 ${ }^{\circ} \mathrm{C} / 21.4$ kbar for the two-pyroxene and orthopyroxenegarnet methods, respectively. Such a large difference in $\mathrm{T} / \mathrm{P}$ estimates for a single sample could be due to disequilibrium among orthopyroxene, clinopyroxene, and garnet, or more likely, the failure of symplectite to preserve the original composition of garnet. In the latter possibility, the error in T/P estimate would be compounded by utilizing an incorrect garnet composition in both the orthopyroxene-garnet temperature estimate and the $\mathrm{Al}-\mathrm{in}-\mathrm{Opx}$ pressure estimate. Both $\mathrm{T} / \mathrm{P}$ results lie above the geotherm established for Kozákov volcano at the time of eruption (Christensen et al. 2001), which also suggests that the T/P results utilizing the symplectite composition may be spurious. Note that combining the two-pyroxene temperature estimate for KOZ-4 with the Kozákov geotherm at the time of eruption yields a depth of $\sim 73 \mathrm{~km}$ and pressure of $\sim 23 \mathrm{kbar}$.

\section{Geochemistry}

Trace-element concentrations were analysed for clinopyroxene in all xenolith samples (Tab. 8), and, in the case of websterite KOZ-4, also for symplectite pseudomorphs (Tab. 9). Sr-Nd isotopic compositions (Tab. 10) were determined on acid-leached clinopyroxene separates, except for xenolith KOZ-17, which did not yield enough clinopyroxene for isotope analysis.

\subsection{Trace-element data}

Rare earth element (REE) and extended trace-element patterns for clinopyroxene, all normalized to primitive mantle (McDonough and Sun 1995), are shown in Figs 8 and 9 , respectively.

Clinopyroxenes from Kozákov websterite KOZ-5 and clinopyroxenite KOZ-17 show subparallel LREE- 

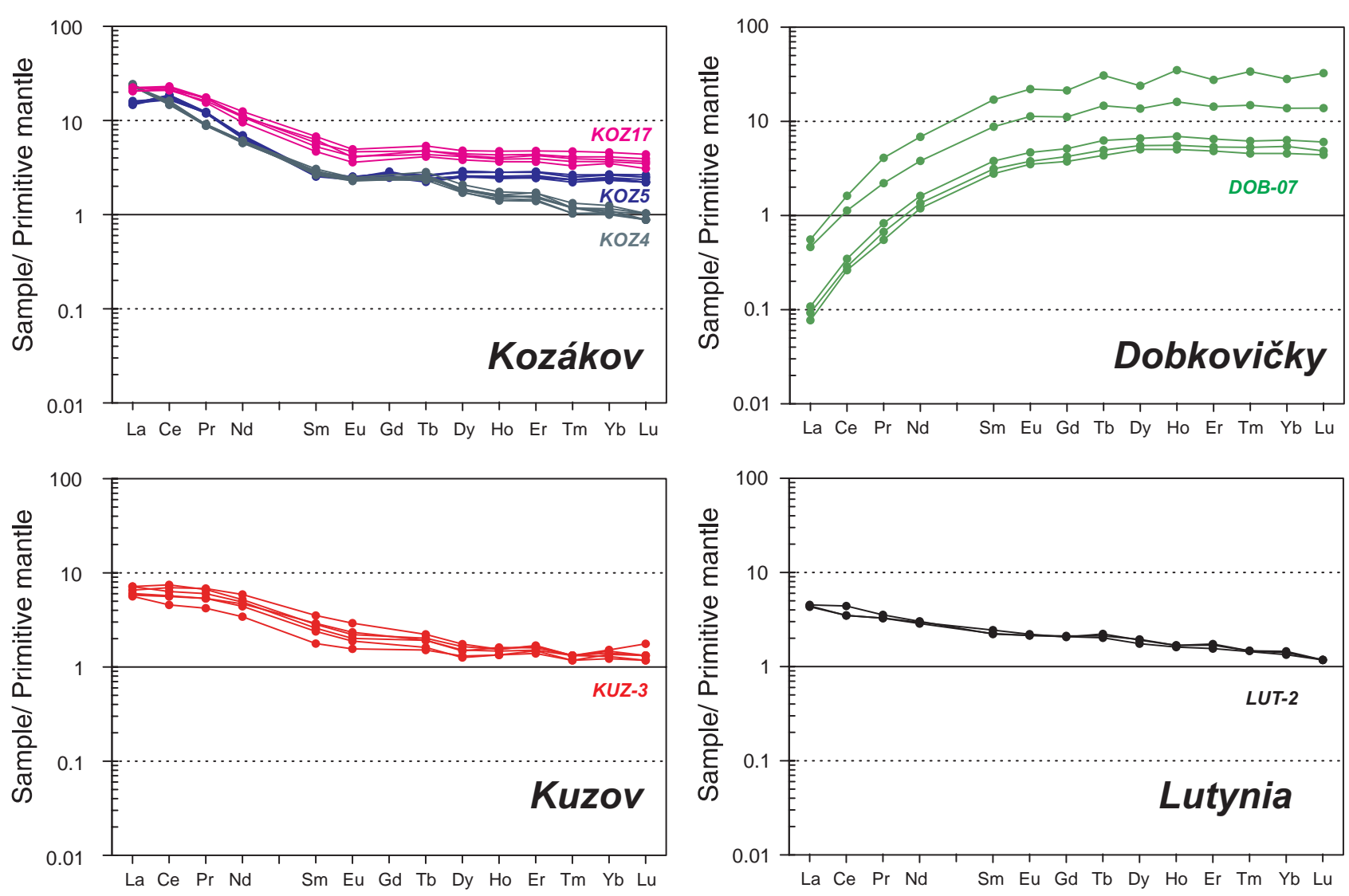

Fig. 8 Rare earth element patterns of clinopyroxenes from the studied pyroxenite, normalized to primitive mantle (McDonough and Sun 1995).

enriched patterns $\left(\mathrm{La}_{\mathrm{N}} / \mathrm{Yb}_{\mathrm{N}}=5.3-6.4\right)$, with KOZ-5 having overall lower REE abundances (Fig. 8). The patterns show minor to no fractionation from $\mathrm{Eu}$ to $\mathrm{Lu}$. In contrast, clinopyroxene in pseudomorph-bearing websterite KOZ-4 exhibits an overall depletion in the HREE, resulting in higher $\mathrm{La}_{\mathrm{N}} / \mathrm{Yb}_{\mathrm{N}}$ ratios (19.5-23.0). None of the Kozákov samples features a Eu anomaly. Extended trace-element patterns of all clinopyroxenes show enrichment in $\mathrm{U}$, Th, and $\mathrm{Nb}$, but depletions in $\mathrm{Zr}, \mathrm{Hf}, \mathrm{Rb}$, and $\mathrm{Pb}$ comparing to primitive upper mantle (Fig. 9). All of these patterns are similar to those of clinopyroxene in Kozákov lherzolites from the lower equigranular (66$70 \mathrm{~km}$ depth) layer (Ackerman et al. 2007). In addition, clinopyroxene from KOZ-17 displays a marked depletion in Sr. The symplectite pseudomorphs from KOZ-4 websterite show a marked positive slope from the LREE to the HREE, which is typical for mantle garnets, except for an enrichment in La relative to Ce (Fig. 10). Rubidium, $\mathrm{U}$, and $\mathrm{Nb}$ are all enriched relative to $\mathrm{La}$, and Th shows a negative anomaly relative to $\mathrm{U}$ and $\mathrm{Rb}$. strontium is variable, with some symplectite grains being enriched relative to $\mathrm{Nd}$, and others depleted (Fig. 10). Lead shows a range of normalized values, all being enriched relative to Nd (Fig. 10).
Clinopyroxene grains in xenolith DOB-7 show subparallel REE patterns, which have a distinct depletion in the LREE and a flat distribution of the HREE (Fig. 8). This clinopyroxene REE pattern is very different from that reported for a whole-rock clinopyroxenite xenolith from the same locality, with LREE enrichment and a positive Eu anomaly (Mihaljevič 1993). In the extended trace-element patterns (Fig. 9), the highly incompatible elements $\mathrm{Rb}$ and $\mathrm{Nb}$ are depleted relative to primitive upper mantle. Lead, $\mathrm{Zr}$ and $\mathrm{Y}$ show pronounced negative anomalies (Fig. 9).

Clinopyroxenes from KUZ-3 and LUT-2 xenoliths have similar REE patterns (Fig. 8), both being slightly LREE-enriched $\left(\mathrm{La}_{\mathrm{N}} / \mathrm{Yb}_{\mathrm{N}}=3.0-5.1\right)$. Clinopyroxene grains in KUZ-3 are depleted in $\mathrm{Pb}$ and the high-field strength elements (HFSE) such as $\mathrm{Nb}, \mathrm{Zr}$ and $\mathrm{Hf}$. Rubidium, Th, $\mathrm{U}$, and $\mathrm{Nb}$ are all depleted relative to La. Clinopyroxene grains in LUT-2 show negative $\mathrm{Nb}, \mathrm{Pb}$, and $\mathrm{Zr}$ anomalies (Fig. 9).

\section{2. $\mathrm{Sr}-\mathrm{Nd}$ isotopic composition}

The measured ${ }^{87} \mathrm{Sr} /{ }^{86} \mathrm{Sr}$ and ${ }^{143} \mathrm{Nd} /{ }^{144} \mathrm{Nd}$ isotopic ratios of five acid-leached clinopyroxene separates (Tab. 10) are 

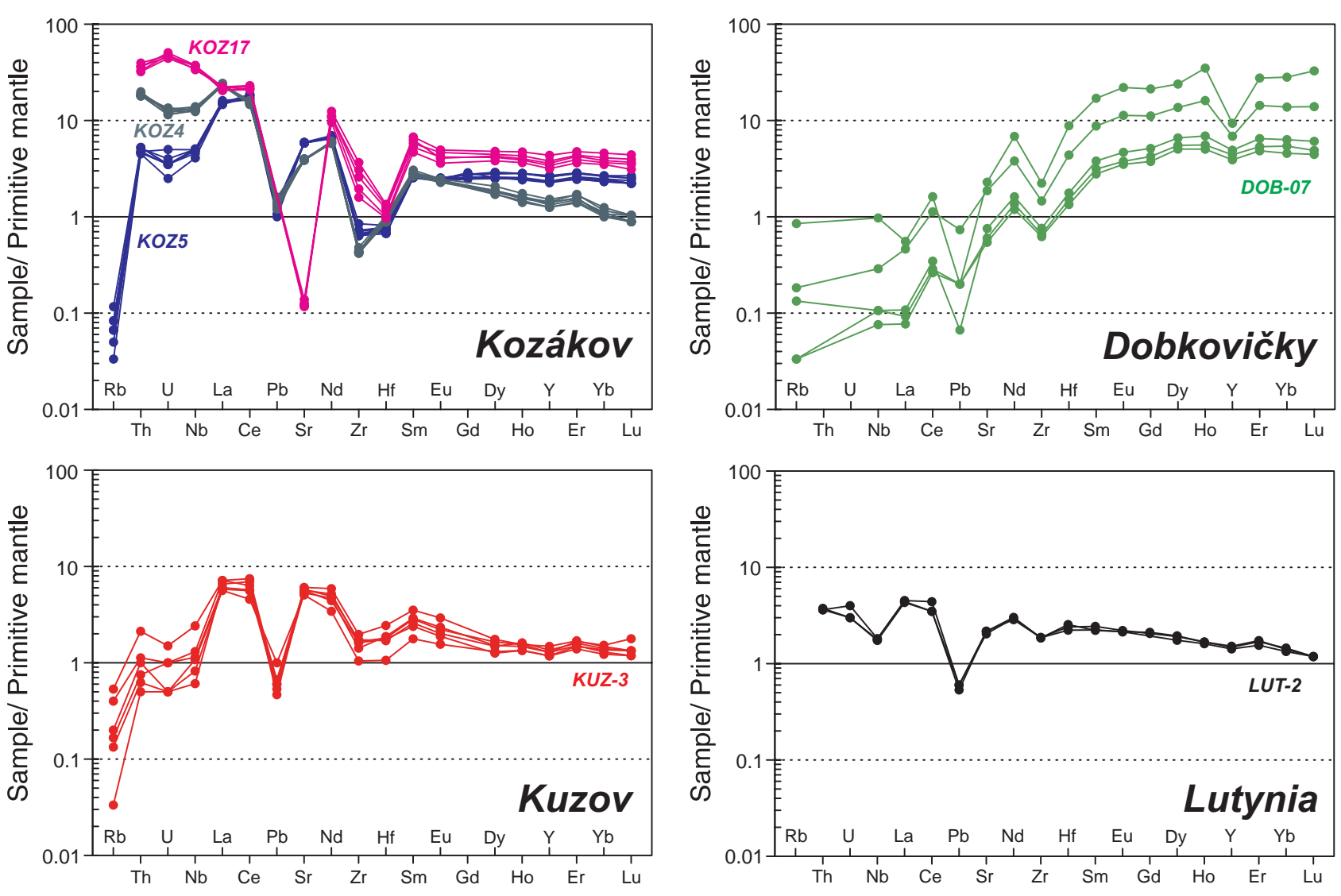

Fig. 9 Extended trace-element patterns of clinopyroxenes from the studied pyroxenite, normalized to primitive mantle (McDonough and Sun 1995).

plotted in Fig. 11, together with data from Quaternary pyroxenite xenoliths from the Eifel in western Germany and Cenozoic volcanic rocks in the CEVP. The samples show a wide range in $\varepsilon_{\mathrm{Nd}}$ values $(+2.6$ to +8.9$)$. There is no co-variation of $\mathrm{Sm} / \mathrm{Nd}$ ratios and $\mathrm{Nd}$ isotopic compositions, indicating that the variable degrees of fractionation of mother/daughter isotopes have occurred rather recently, possibly during Tertiary volcanism. Surprisingly, the large spread in $\mathrm{Nd}$ isotopic ratios contrasts with the small variation in ${ }^{87} \mathrm{Sr} /{ }^{86} \mathrm{Sr}$ ratios, which for four samples lie between 0.70335 and 0.70350 . The data points thus form a nearly vertical array, rather than showing the negative correlation of $\mathrm{Sr}-\mathrm{Nd}$ isotope data that is typical of the Mantle Array (Fig. 11). Sample DOB-07 with the highest $\varepsilon_{\mathrm{Nd}}$ value of 8.9 also has the highest ${ }^{87} \mathrm{Sr} /{ }^{86} \mathrm{Sr}$ ratio of 0.7037 . The isotope data demonstrate decoupling of $\mathrm{Sr}$ and $\mathrm{Nd}$ in pyroxenite of the Bohemian lithospheric mantle, which is a phenomenon also displayed by peridotite xenoliths from Kozákov (Ackerman et al. 2007). In contrast, clinopyroxene separates from Eifel pyroxenites (Witt-Eickschen and Kramm 1998; Witt-Eickschen et al. 2003) show a negative correlation for Sr-Nd isotopic compositions that overlap the Mantle Array and are isotopically similar to European mantle peridotites (see
Downes 2001 and references therein). Except for the outlier sample DOB-07, values of $\varepsilon_{\mathrm{Nd}}$ and ${ }^{87} \mathrm{Sr} /{ }^{86} \mathrm{Sr}$ for the pyroxenite xenoliths investigated here lie within the field for Tertiary-Quaternary basalts of the CEVP (Fig. 11).

\section{Discussion}

To date only a few studies on pyroxenite mantle xenoliths from the European Cenozoic volcanics have been published, and models for their origin and composition of the lithospheric mantle are still poorly constrained. Puziewicz et al. (2011) studied clinopyroxenite and websterite xenoliths from Księnginki volcano, which is located on the eastern shoulder of the NE-SW trending Ohře/ Eger rift system in Poland, and suggested an origin as cumulates from alkaline melts with a composition similar to that of the hosting basalts. Witt-Eickschen and Kramm (1998) argued that clinopyroxenites from the Eifel in Germany represent high-pressure cumulates of magmas, whose compositions were similar to, or more primitive than, that of the hosting basalts. In the Bohemian Massif, garnet-bearing pyroxenites (websterite to clinopyroxenite) are common in the high-temperature/high-pressure 

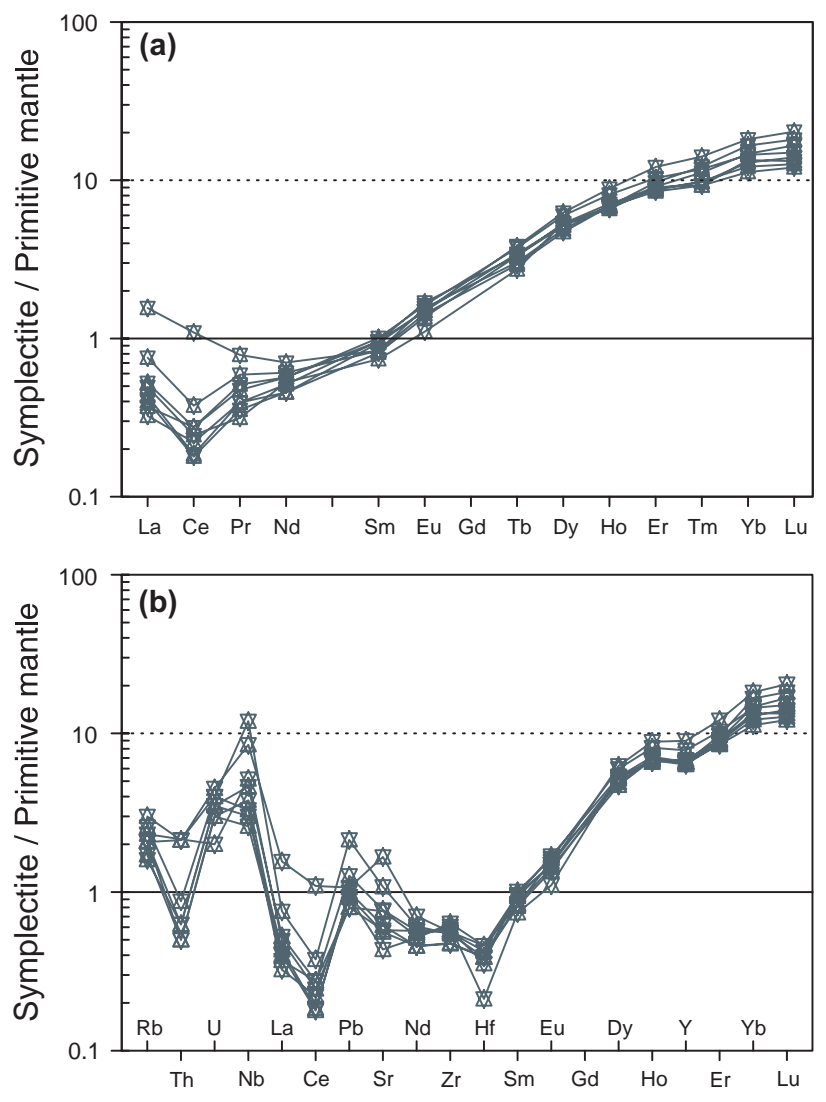

Fig. 10 Rare earth element (a) and extended trace-element (b) patterns of symplectite pseudomorphs after garnet in Kozákov websterite sample KOZ-4, normalized to primitive mantle (McDonough and Sun 1995).

(HT-HP) Moldanubian and Kutná Hora units, where they occur as layers, lenses, or veins in HT-HP garnet peridotites in granulite and/or paragneiss. Their major-element, trace-element and Sr-Nd isotopic compositions suggest that they likely represent high-pressure cumulates from transient subduction-related upper mantle melts and/or crystallization products of melt-rock reactions between peridotite and these melts (Medaris et al. 1995; Becker 1996; Ackerman et al. 2009). Mica-bearing clinopyroxenite xenoliths in melilitic rocks of the Osečná Complex in northern Bohemia may represent metasomatized upper mantle (Ulrych et al. 2000). High CaO contents in alkaline basaltic rocks throughout the Bohemian Massif support a clinopyroxene-dominated mantle source and an origin as partial melts of clinopyroxene-veined mantle (e.g., Lloyd et al. 1991). Abratis et al. (2009) interpreted geochemical and mineralogical data of Cenozoic melilitic volcanic rocks from the Erzgebirge, forming an uplifted shoulder of the Ohře/Eger Rift, as evidence for very low degrees of melting of a pervasively metasomatized, $\mathrm{CO}_{2}$ rich mantle beneath the Bohemian Massif.

Because clinopyroxene is the principal carrier of REE in a spinel peridotite mantle free of secondary metasomatic phases (e.g., amphibole, apatite), the composition of melts equilibrated with clinopyroxene can be calculated using $\mathrm{Cpx} /$ basanite partitioning coefficients (Fig. 12). The REE patterns for the calculated melts in KOZ-5 and KOZ-17 are very similar, despite of the differences in temperature estimates (1008-1067 ${ }^{\circ} \mathrm{C}$ vs. 596-663 ${ }^{\circ} \mathrm{C}$ ), mode (websterite vs. olivine clinopyroxenite), and texture. Slightly concave HREE patterns and absence of HREE fractionation $\left(\mathrm{Dy}_{\mathrm{N}} / \mathrm{Lu}_{\mathrm{N}}\right.$ ratios of 1.0) argue for melt derivation in the spinel peridotite stability field. On the other hand, contrasting calculated equilibrium temperatures suggest derivation from different mantle depths. When tectonothermal model of Christensen et al. (2001) is applied, KOZ-5 was likely derived from the depth of $\sim 70 \mathrm{~km}$ and KOZ-17 from $\sim 35 \mathrm{~km}$.

The websterite sample KOZ-4, which contains symplectite pseudomorphs after garnet, records a complex evolution, beginning with HT crystallization of coarsegrained, Al-rich clinopyroxene. This was followed by partial recrystallization and subsolidus re-equilibration, resulting in formation of the porphyroclastic texture and development of orthopyroxene and garnet exsolution lamellae in clinopyroxene. The pressure (and depth) under which garnet exsolution occurred is uncertain, due to the equivocal symplectite compositions. Subsequently, garnet was transformed to an orthopyroxene-plagioclase symplectite through a reaction such as $\mathrm{Mg}_{3} \mathrm{Al}_{2} \mathrm{Si}_{3} \mathrm{O}_{12}$ (garnet) $+\mathrm{CaMgSi}_{2} \mathrm{O}_{6}$ (clinopyroxene) $+\mathrm{SiO}_{2}$ (melt) $=$ $2 \mathrm{Mg}_{2} \mathrm{Si}_{2} \mathrm{O}_{6}$ (orthopyroxene) $+\mathrm{CaAl}_{2} \mathrm{Si}_{2} \mathrm{O}_{8}$ (plagioclase) The presence of substantial amounts of $\mathrm{Na}$ in symplectite, positive anomalies for $\mathrm{Rb}, \mathrm{U}, \mathrm{Nb}, \mathrm{La}$, and $\mathrm{Pb}$, and the addition of $\mathrm{SiO}_{2}$ necessary to balance the reaction, all imply that silicate melt was involved in the garnet breakdown. The extremely fine grain size of orthopyroxene and plagioclase in symplectite indicates rapid cooling, and this, combined with the apparent influence of melt in the development of symplectite, suggests that garnet breakdown occurred during entrainment and transport of the xenolith by the host basanite. The REE patterns of clinopyroxene (Fig. 9) and calculated melt (Fig. 12), which has a $\mathrm{Dy}_{\mathrm{N}} / \mathrm{Lu}_{\mathrm{N}}$ ratio of 1.7 , demonstrate that the parental melt from which the pyroxenite formed was derived in the garnet peridotite stability field. The $\varepsilon_{\mathrm{Nd}}$ values of +5.0 and +3.3 in clinopyroxene separates from xenoliths KOZ-4 and KOZ-5 (Fig. 11) lie within the range $(+4.6$ to 8.5$)$ reported for clinopyroxene from Kozákov peridotite xenoliths (Ackerman et al. 2007). This may reflect the long-term history of the xenoliths, e.g. a heterogeneous lithospheric mantle and/or different $\mathrm{Sm} / \mathrm{Nd}$ ratios due to variable degrees of partial melting in the source of the pyroxenite melts. On the other hand, ${ }^{87} \mathrm{Sr} /{ }^{86} \mathrm{Sr}$ ratios of clinopyroxene separates (0.70343-0.70347) are higher than those from Kozákov basanite (0.70311-0.70340; Lustrino and Wilson 2007), suggesting a pervasive metasomatic overprint by melts 
Fig. 11 Measured Sr and Nd isotopic compositions of acid-leached clinopyroxene samples from the studied xenoliths. Note the large variation in $\varepsilon \mathrm{Nd}$ values at similar ${ }^{87} \mathrm{Sr} /{ }^{86} \mathrm{Sr}$ ratios, suggesting decoupling between the $\mathrm{Rb}-\mathrm{Sr}$ and $\mathrm{Sm}-$ Nd systems. Data for Eifel pyroxenite xenoliths are from Witt-Eickschen and Kramm (1998) and Witt-Eickschen et al. (2003). The field of CEVP Cenozoic volcanic rocks is based on data of Alibert et al. (1983, 1987), Blusztajn and Hart (1989), Bendl et al. (1993), Ulrych et Wilson (2007) and Ulrych (unpublished data). DMM = Depleted MORB Mantle composition (Workman and Hart 2005). $\mathrm{BSE}=$ Bulk Silicate Earth. al. (1998, 2000, 2002), Lustrino and

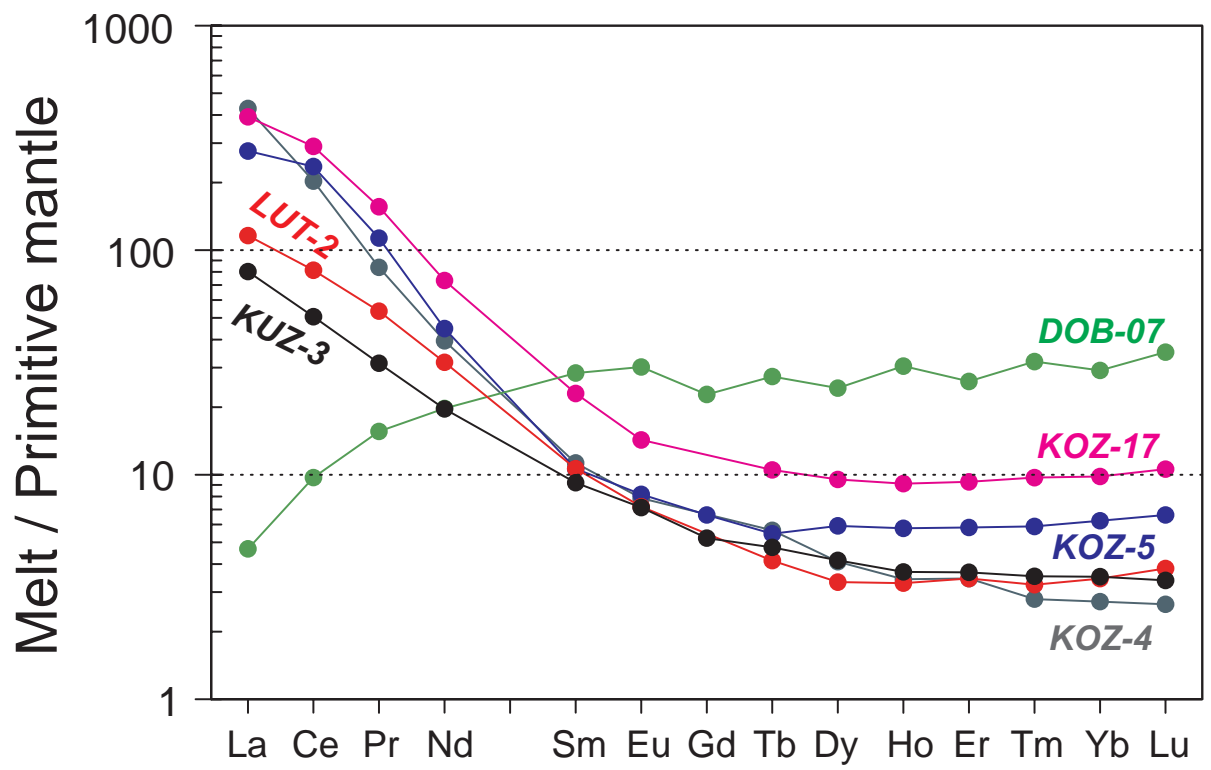

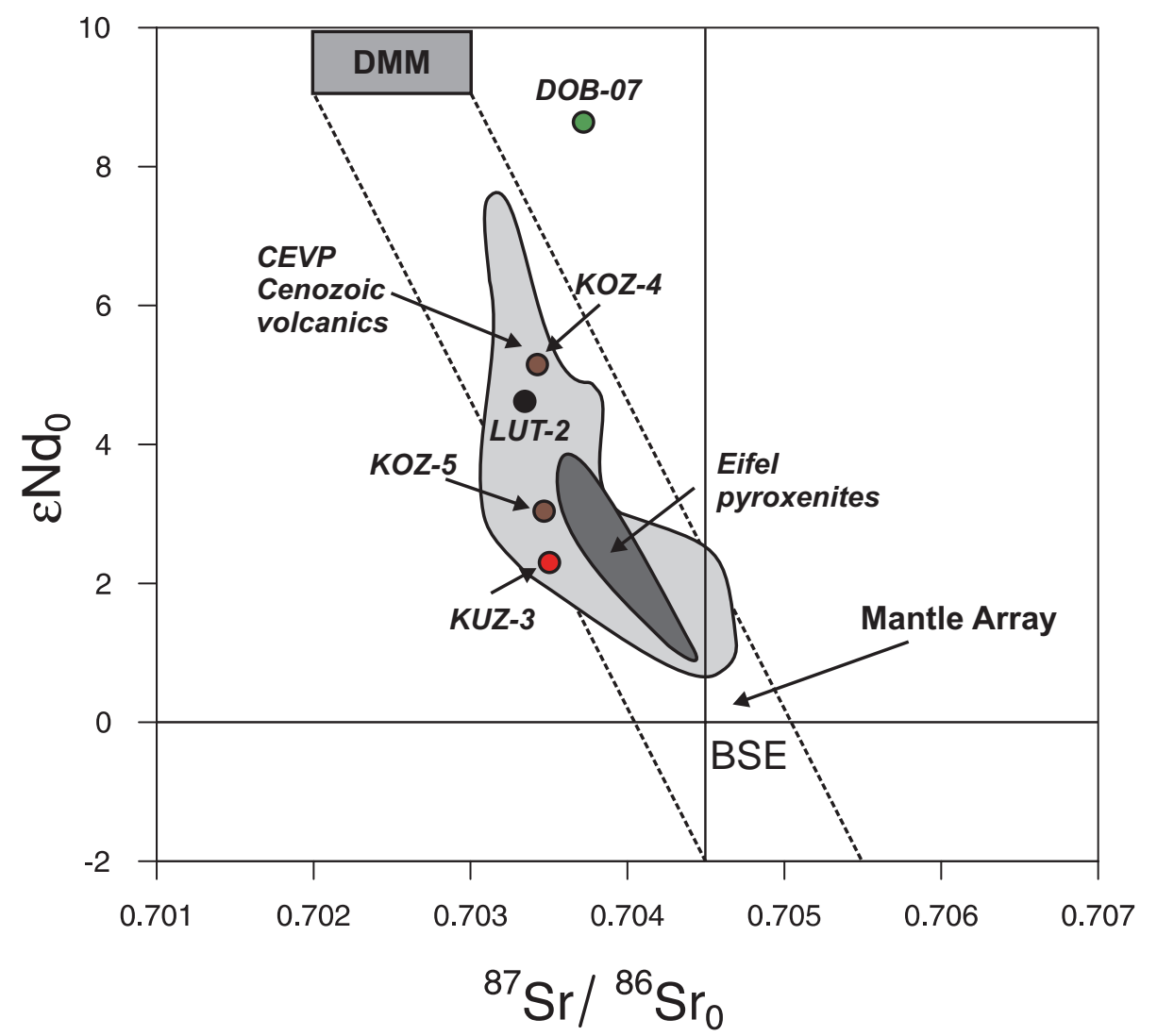

Fig. 12 Calculated REE composition for melt in equilibrium with clinopyroxene (normalized to primitive mantle; McDonough and Sun 1995). Partitioning coefficients used are from Norman (1998), Green et al. (2000) and Adam and Green (2006). with a more radiogenic Sr composition than that of the host basanite.

The Dobkovičky websterite DOB-07 has a characteristic cumulate texture (Fig. 5a-b), although the LREE and other incompatible trace-element depletions in clinopyroxene preclude derivation as a cumulate from the host basanite. For example, the calculated melt, from which the clinopyroxene crystallized, shows a pronounced
LREE depletion (Fig. 12; $\mathrm{La}_{\mathrm{N}} / \mathrm{Yb}_{\mathrm{N}}=0.27$ ) in contrast to the host basanite, which is LREE enriched $\left(\mathrm{La}_{\mathrm{N}} / \mathrm{Yb}_{\mathrm{N}}=\right.$ 22.6-23.2; Ackerman, unpublished data). A cumulate origin from the host basanite is also precluded by the highly radiogenic $\varepsilon_{\mathrm{Nd}}(+8.9)$ in clinopyroxene, compared to that in the host basanite $\left(\varepsilon_{\mathrm{Nd}}=+3.9\right.$ to +4.0 ; Ackerman, unpublished data). Rather, trace-element and $\mathrm{Sr}-\mathrm{Nd}$ isotopic compositions point to a lithospheric mantle source with 
an ancient depletion in incompatible elements, similar to MORB depleted mantle. Such a composition has only been reported in the Bohemian Massif for the Mohelno peridotite body, located in the HT-HP Gföhl Unit of the Moldanubian Zone (Medaris et al. 2005).

The Kuzov and Lutynia websterites display mutually comparable REE patterns for clinopyroxene and for the calculated melt (Fig. 12). However, their clinopyroxene ${ }^{143} \mathrm{Nd} /{ }^{144} \mathrm{Nd}$ compositions differ significantly $\left(\varepsilon_{\mathrm{Nd}}=+2.6\right.$ and +4.9 , respectively). The Kuzov peridotite xenoliths have not been studied in detail yet, therefore the relationship between the pyroxenite studied here and peridotites remain unclear. However, the presence of olivine, the absence of spinel, variable trace-element patterns and $\mathrm{Sr}-\mathrm{Nd}$ isotopic compositions of clinopyroxene similar to those in basanite are all compatible with an origin as cumulates from associated basanitic melts. In Lutynia, cryptic metasomatism of peridotites by $\mathrm{CO}_{2}$-bearing alkaline melt was described by Matusiak-Małek et al. (2010). Using the same partitioning coefficients as those used by these authors, the calculated melt composition in equilibrium with Lutynia websterite clinopyroxene is similar to that in equilibrium with the most metasomatized amphibole-bearing peridotite (Group D peridotites; Matusiak-Małek et al. 2010). Therefore, the Lutynia websterite xenolith may be interpreted as a cumulate from melts that percolated through lithospheric mantle peridotite.

\section{Conclusions}

Mantle pyroxenite xenoliths from Kozákov, Dobkovičky, Kuzov and Lutynia are hosted by Tertiary-Quaternary basanites of the Central European Volcanic Province (CEVP). Detailed investigations of petrography, geothermobarometry, major- and trace-element as well as $\mathrm{Sr}-\mathrm{Nd}$ isotopic compositions reveal a diversity of origins and geochemical evolutions for the studied xenoliths. Two of them from Kozákov volcano, websterite KOZ-5 and clinopyroxenite KOZ-17, have compositions, textures and equilibration temperatures suggesting their derivation from different mantle depths. Sample KOZ-5 comes from a depth of $\sim 70 \mathrm{~km}$, near the base of the Protogranular Layer, and KOZ-17, from $\sim 35 \mathrm{~km}$, near the top of the Upper Equigranular Layer. Kozákov websterite KOZ-4 was derived from a depth of $\sim 73 \mathrm{~km}$ near the boundary between the Protogranular and Lower Equigranular layers and records a complex history, including early hightemperature crystallization, followed by partial recrystallization and re-equilibration, during which orthopyroxene and garnet exsolved from clinopyroxene, and finally, breakdown of garnet to an orthopyroxene + plagioclase symplectite. The websterite from Dobkovičky most likely represents a cumulate from a silicate melt passing through the lithospheric mantle. The LREE-depleted patterns of melt from which the xenolith crystallized and a highly radiogenic Nd suggest its derivation from a highly depleted mantle domain with a composition similar to that of depleted MORB mantle (DMM). The melts calculated for the Kuzov and Lutynia pyroxenites have mutually comparable REE characteristics, although the $\mathrm{Sr}$ and $\mathrm{Nd}$ isotopic compositions of their clinopyroxenes differ. The significance of the Kuzov websterite remains uncertain, because no data exist for the associated peridotite xenoliths. At the Lutynia locality, cryptic metasomatism of peridotites by a $\mathrm{CO}_{2}$-bearing alkaline melt was described previously, and the melt composition calculated to be in equilibrium with the websterite clinopyroxene is similar to that in equilibrium with the most metasomatized amphibole-bearing peridotite. Therefore, the Lutynia websterite may represent a cumulate from percolating melt that metasomatized the lithospheric mantle in this area.

Acknowledgments. We thank Vlasta Böhmová for microprobe analyses, Jana Ďurišová for help with LA-ICPMS analyses, Esther Schmädicke and Michel Grégoire for their constructive reviews and Jana Kotková for comments and manuscript handling. This research was supported by the Grant Agency of the Czech Republic, Project No. 205/09/1170 and the Scientific Programme CEZ: AV0Z30130516 and RVO67985831 of the Institute of Geology v.v.i., Academy of Sciences of the Czech Republic.

\section{References}

Abratis M, Munsel D, Viereck-Götte L (2009) Melilithite und Melilith-führende Magmatite des sächsischen Vogtlands: Petrographie und Mineralchemie. Z Geol Wiss 37: 41-79

Ackerman L, Mahlen N, Jelínek E, Medaris G, Ulrych J, Strnad L, Mihaljevič M (2007) Geochemistry and evolution of subcontinental lithospheric mantle in Central Europe: evidence from peridotite xenoliths of the Kozákov Volcano, Czech Republic. J Petrol 48: 2235-2260

Ackerman L, Jelínek E, Medaris G, Ježek J, Siebel W, StRnAd L (2009) Geochemistry of Fe-rich peridotites and associated pyroxenites from Horní Bory, Bohemian Massif: insights into subduction-related melt-rock reactions. Chem Geol 259: 152-167

Adam J, Green T (2006) Trace element partitioning between mica- and amphibole-bearing garnet lherzolite and hydrous basanitic melt: 1 . experimental results and the investigation of controls on partitioning behaviour. Contrib Mineral Petrol 152: 1-17 
Alibert C, Letterrier J, Panasiuk M, Zimmerman JL (1987) Trace and isotope geochemistry of the alkaline Tertiary volcanism in southwestern Poland. Lithos 20: 311-321

Alibert C, Michard A, Albarede F (1983) The transition from alkali basalts to kimberlites: isotope and trace element evidence from melilitites. Contrib Mineral Petrol 82: 176-186

BABušKa V, Plomerová J (1992) The lithosphere in central Europe - seismological and petrological aspects. Tectonophysics 207: 141-163

BABUŠKa V, Plomerová J (2010) Mantle lithosphere control of crustal tectonics and magmatism of the western Ohře (Eger) Rift. J Geosci 55: 171-186

Babuška V, Fiala J, Plomerová J (2010) Bottom to top lithosphere structure and evolution of western Eger Rift (Central Europe). Int J Earth Sci 99: 891-907

Ballhaus C, Berry RF, Green DH (1991) High pressure experimental calibration of olivine-orthopyroxene-spinel oxygen geobarometer: implications for the oxidation state of the upper mantle. Contrib Mineral Petrol 107: 27-40

BECKER H (1996) Crustal trace element and isotopic signatures in garnet pyroxenites from garnet peridotite massifs from Lower Austria. J Petrol 37: 785-810

Bendl J, Vokurka K, Sundvoll B (1993) Strontium and neodymium isotope study of Bohemian basalts. Mineral Petrol 48: 35-45

Bertrand P, Mercier J-CC (1985) The mutual solubility of coexisting ortho- and clinopyroxene: toward an absolute geothermometer for the natural system? Earth Planet Sci Lett 76: 109-122

Birkenmajer K, Pécskay Z, Grabowski J, Lorenc MW, ZAGOZDZON PP (2002) Radiometric dating of the Tertiary volcanics in Lower Silesia, Poland. II. K-Ar and paleomagnetic data from Neogene basanites near Lądek Zdrój, Sudetes Mountains. Ann Soc Geol Pol 72: 119-121

Birkenmajer K, LoRenc MW, PÉCSKAy Z, Zagozdzon PP (2004) Age, cycles and course of migration of the Tertiary basaltic volcanism in Lower Silesia in the light of K-Ar dating. VIII. Ogólnopolska Sesja Naukowa Datowanie mineralów i skal. 9-10

Blusztajn J, HART SR (1989) Sr, Nd, and Pb isotopic character of Tertiary basalts from southwest Poland. Geochim Cosmochim Acta 53: 2689-2696

Bouvier A, Vervoort JD, Patchett PJ (2008) The Lu-Hf and $\mathrm{Sm}-\mathrm{Nd}$ isotopic composition of CHUR: constraints from unequilibrated chondrites and implications for the bulk composition of terrestrial planets. Earth Planet Sci Lett 273: 48-57

BREY GP, KöHLER T (1990) Geothermobarometry in fourphase lherzolites: II. new thermobarometers and practical assessment of existing thermobarometry. J Petrol 31: 1352-1378

Chen S, O'Reilly SY, Zhou X, Griffin WL, Zhang G, Sun M, Feng J, Zhang M (2001) Thermal and petrological structure of the lithosphere beneath Hannuoba, SinoKorean Craton, China: evidence from xenoliths. Lithos 56: 267-301

Christensen N., Medaris LG, Wang HF, Jelínek E (2001) Depth variation of seismic anisotropy and petrology in central European lithosphere: a tectonothermal synthesis from spinel lherzolite. J Geophys Res 106: 645-664

Davies G, Nixon P, Pearson D, Obata M (1993) Tectonic implications of graphitized diamonds from the Ronda peridotite massif, Southern Spain. Geology 21: 471-474

Dick HJB, SinTon J (1979) Compositional layering in Alpine peridotites - evidence for pressure solution creep in the mantle. J Geol 87: 403-416

Downes H (2001) Formation and modification of the shallow sub-continental lithospheric mantle: a review of geochemical evidence from ultramafic xenolith suites and tectonically emplaced ultramafic massifs of western and central Europe. J Petrol 42: 233-250

Downes H (2007) Origin and significance of spinel and garnet pyroxenites in the shallow lithospheric mantle: ultramafic massifs in orogenic belts in Western Europe and NW Africa. Lithos 99: 1-24

Fediuk F (1994) Deep-origin xenoliths in volcanics of Czechoslovakia. In: Bucha V, BlížKovskÝ M (eds) Crustal Structure of the Bohemian Massif and the West Carpathians. Springer, New York, pp 277-281

Fediuk F, Fediuková E (1985) Postmesozoic alkaline volcanics of northern Moravia (Czechoslovakia). Acta Univ Carol, Geol 4: 355-382

Fediuk F, Fediuková E (1989) Ultramafic nodules from basaltoids of northern Moravia, Czechoslovakia. Sbor Geol Věd, Geol 44: 9-49

Franke W (1989) Variscan plate tectonics in Central Europe - current ideas and open questions. Tectonophysics 169: 221-228

Frey F (1980) The origin of pyroxenites and garnet pyroxenites from Salt-Lake crater, Oahu, Hawaii - trace element evidence. Amer J Sci 280: 427-449

FRÝDA J, VOKURKA K (1995) Evidence for carbonatite metasomatism in the upper mantle beneath the Bohemian Massif. J Czech Geol Soc 43: 9-10

Galán G, Oliveras V, Paterson BA (2011) Thermal and redox state of the subcontinental lithospheric mantle of NE Spain from thermobarometric data on mantle xenoliths. Int J Earth Sci 100: 81-106

Gonzaga RG, Lowry D, Jacob DE, LeRoex A, Schulze D, Menzies MA (2010a) Eclogites and garnet pyroxenites: similarities and differences. J Volcanol Geoth Res 190: 235-247

Gonzaga RG, Menzies MA, Thirlwall MF, Jacob DE, Leroex A (2010b) Eclogites and garnet pyroxenites: problems resolving provenance using $\mathrm{Lu}-\mathrm{Hf}, \mathrm{Sm}-\mathrm{Nd}$ and $\mathrm{Rb}-\mathrm{Sr}$ isotope systems. J Petrol 51: 513-535 
Green T., Blundy J., Adam J, Yaxley G. (2000) SIMS determination of trace element partition coefficients between garnet, clinopyroxene and hydrous basaltic liquids at $2-7.5 \mathrm{GPa}$ and $1080-1200^{\circ} \mathrm{C}$. Lithos $53: 165-187$

HARLEY S (1984) Comparison of the garnet-orthopyroxene geobarometer with recent experimental studies, and applications to natural assemblages. J Petrol 25: 697-712

Hegner E, Walter HJ, Satir M (1995) Pb-Sr-Nd isotopic compositions and trace element geochemistry of megacrysts and melilitites from the Tertiary Urach volcanic field: source composition of small volume melts under SW Germany. Contrib Mineral Petrol 122: 322-335

Horn I, Rudnick RL, McDonough WF (2000) Precise elemental and isotope ratio determination by simultaneous solution nebulization and laser ablation-ICP-MS: application to U-Pb geochronology. Chem Geol 164: 281-301

JANOUŠEK V, FARROW CM, ERBAN V (2006) Interpretation of whole-rock geochemical data in igneous geochemistry: introducing Geochemical Data Toolkit (GCDkit). J Petrol 47: 1255-1259

Jochum KP, Enzweiler J, Mertz-Kraus R, Wang X (2010) GGR biennial review: reference materials in geoanalytical and environmental research - review for 2008 and 2009. Geost Geoanal Res 34: 353-385

KopeckÝ L (1978) Neoidic taphrogenic evolution of young alkaline volcanism of the Bohemian Massif. Sbor geol Věd, Geol 30: 91-107

KRETZ R (1983) Symbols for rock-forming minerals. Amer Miner 68: 277-279

Lloyd FE, Huntingdon AT, Davies G, Nixon PH (1991) Phanerozoic volcanism of southwest Uganda. A case for regional $\mathrm{K}$ and LILE enrichment of the lithosphere beneath a domed and rifted continental plate. In: KAMPunZu AB, Lubala RT (eds) Magmatism in Extensional Structural Settings. Springer, Berlin, pp 23-72

Loubet M, Allėgre CJ (1982) Trace elements in orogenic lherzolites reveal the complex history of the upper mantle. Nature 298: 809-814

Lustrino M, WiLson M (2007) The circum-Mediterranean anorogenic Cenozoic igneous province. Earth Sci Rev 81: 1-65

Matusiak-Malek M, Puziewicz J, Ntaflos T, Grégoire M, Downes H (2010) Metasomatic effects in the lithospheric mantle beneath the NE Bohemian Massif: a case study of Lutynia (SW Poland) peridotite xenoliths. Lithos 117: 49-60

McDonough WF, Sun S (1995) The composition of the Earth. Chem Geol 120: 223-253

Medaris LG, Beard BL, Johnson CM, Valley JW, Spicuzza MJ, JeLínek E, Mísař Z (1995) Garnet pyroxenite and eclogite in the Bohemian Massif: geochemical evidence for Variscan recycling of subducted lithosphere. Geol Rundsch 84: 489-505
Medaris LG, Wang H, Jelínek E, Mihaljevič M, Jakeš P (2005) Characteristics and origins of diverse Variscan peridotites in the Gföhl Nappe, Bohemian Massif, Czech Republic. Lithos 82: 1-23

Mercier J-CC, Nicolas A (1975) Textures and fabrics of upper-mantle peridotites as illustrated by xenoliths from basalts. J Petrol 16: 454-487

MERLET C (1994) An accurate computer correction program for quantitative electron-probe microanalyses. Microchim Acta 114: 363-376

MinalJEviČ M (1993) Geochemistry of Olivine-Free Ultramafic Xenoliths from the České Středohoří Mts. Unpublished PhD. Thesis, Charles University, Prague pp 1-113

Norman MD (1998) Melting and metasomatism in the continental lithosphere: laser ablation ICPMS analysis of minerals in spinel lherzolites from eastern Australia. Contrib Mineral Petrol 130: 240-255

Pearce NJG, Perkins Wt, Westgate Ja, Gorton MP, JackSON SE, NEAL CR, Chenery SP (1997) A compilation of new and published major and trace element data for NIST SRM 610 and NIST SRM 612 glass reference materials. Geostand Newsl 21: 115-144

Pearson D, Davies G, Nixon P (1993) Geochemical constraints on the petrogenesis of diamond facies pyroxenites from the Beni Bousera peridotite massif, North Morocco. J Petrol 34: 125-172

Porreca C, Selverstone J, Samuels K (2006) Pyroxenite xenoliths from the Rio Puerco volcanic field, New Mexico: melt metasomatism at the margin of the Rio Grande Rift. Geosphere 2: 333

Prodehl C, Mueller S, Haak V (1995) The European Cenozoic rift system. In: Olsen KH (ed) Continental Rifts: Evolution, Structure, Tectonics. Elsevier, Amsterdam, pp 133-212

Puziewicz J, Koepke J, Grégoire M, Ntaflos T, MatusiakMaŁeK M (2011) Lithospheric mantle modification during Cenozoic rifting in Central Europe: evidence from the Księginki nephelinite (SW Poland) xenolith suite. J Petrol 52: 2107-2145

ŠIBRAVA V, HaVlí̌́̌EK P (1980) Radiometric age of Plio-Pleistocene volcanic rocks in the Bohemian Massif. Věst Úst Úst Geol 55: 129-150

TAYLOR WR (1998) An experimental test of some geothermometer and geobarometer formulations for upper mantle peridotites with application to the thermobarometry of fertile lherzolite and garnet websterite. Neu Jb Mineral, Abh 172: 381-408

Ulrych J, Lloyd FE, Balogh K (2003) Age relations and geochemical constraints of Cenozoic alkaline volcanic series in W Bohemia: a review. Geolines 15: 168-180

Ulrych J, Pivec E, Langrová A, Jelínek E, Arva-Sos E, HöHNDORF A, BENDL J, ŘANDA Z (1998) Geochemically anomalous olivine-poor nephelinite of Říp Hill, Czech Republic. J Czech Geol Soc 43: 299-312 
Ulrych J, Pivec E, Povondra P, Rutsek J (2000) Uppermantle xenoliths in melilitic rocks of the Osečná Complex, North Bohemia. J Czech Geol Soc 45: 79-83

Ulrych J, Svobodová J, Balogh K (2002) The source of Cenozoic volcanism in the České Středohoří Mts., Bohemian Massif. Neu Jb Mineral, Abh 177: 133-162

Ulrych J, Dostal J, Adamovič J, Jelínek E, Špaček P, HegNer E, BALogh K (2011) Recurrent Cenozoic volcanic activity in the Bohemian Massif(Czech Republic). Lithos 123: $133-144$

Wilson M, Downes H (1991) Tertiary-Quaternary extension-related alkaline magmatism in Western and Central Europe. J Petrol 32: 811-849

Witt-Eickschen G, Kramm U (1998) Evidence for the multiple stage evolution of the subcontinental lithospheric mantle beneath the Eifel (Germany) from pyroxenite and composite pyroxenite/peridotite xenoliths. Contrib Mineral Petrol 131: 258-272

Witt-Eickschen G, Seck HA, Mezger K, Eggins SM, AltHERR R (2003) Lithospheric mantle evolution beneath the Eifel (Germany): constraints from $\mathrm{Sr}-\mathrm{Nd}-\mathrm{Pb}$ isotopes and trace element abundances in spinel peridotite and pyroxenite xenoliths. J Petrol 44: 1077-1095

WORKMAN RK, HART SR (2005) Major and trace element composition of the depleted MORB mantle (DMM). Earth Planet Sci Lett 231: 53-72

Ziegler P (1994) Cenozoic rift system of Western and Central Europe - an overview. Geol en Mijnbw 73: 99-127 